\title{
Evaluation of Maraging Steel Produced Using Hybrid Additive/Subtractive Manufacturing
}

\author{
Sheida Sarafan ${ }^{1, *}$, Priti Wanjara ${ }^{1}{ }^{(\mathbb{D}}$, Javad Gholipour ${ }^{1}$, Fabrice Bernier ${ }^{1}{ }^{(\mathbb{C},}$, Mahmoud Osman ${ }^{1,2}$, Fatih Sikan ${ }^{1,2}$, \\ Marjan Molavi-Zarandi ${ }^{1}$, Josh Soost ${ }^{3}$ and Mathieu Brochu ${ }^{2}$ \\ 1 National Research Council Canada, Montréal, QC H3T 1J4, Canada; Priti.Wanjara@cnrc-nrc.gc.ca (P.W.); \\ Javad.GholipourBaradari@cnrc-nrc.gc.ca (J.G.); Fabrice.Bernier@cnrc-nrc.gc.ca (F.B.); \\ Mahmoud.Osman@cnrc-nrc.gc.ca or mahmoud.osman@mail.mcgill.ca (M.O.); \\ faith.sikan@cnrc-nrc.gc.ca or fatih.sikan@mail.mcgill.ca (F.S.); Marjan.Molavi-Zarandi@cnrc-nrc.gc.ca (M.M.-Z.) \\ 2 Department of Mining and Materials Engineering, McGill University, Montréal, QC H3A 0C5, Canada; \\ mathieu.brochu@mcgill.ca \\ 3 Matsuura Machinery USA Inc., St. Paul, MN 55102, USA; Josh.Soost@matsuurausa.com \\ * Correspondence: Sheida.Sarafan@cnrc-nrc.gc.ca
}

check for updates

Citation: Sarafan, S.; Wanjara, P.; Gholipour, J.; Bernier, F.; Osman, M.; Sikan, F.; Molavi-Zarandi, M.; Soost, J.; Brochu, M. Evaluation of Maraging Steel Produced Using Hybrid Additive/Subtractive Manufacturing. J. Manuf. Mater. Process. 2021, 5, 107. https://doi.org/10.3390/jmmp 5040107

Academic Editors: Hao Wang and Jerry Fuh

Received: 17 September 2021

Accepted: 5 October 2021

Published: 12 October 2021

Publisher's Note: MDPI stays neutral with regard to jurisdictional claims in published maps and institutional affiliations.

\begin{abstract}
Hybrid manufacturing is often used to describe a combination of additive and subtractive processes in the same build envelope. In this research study, hybrid manufacturing of $18 \mathrm{Ni}-300$ maraging steel was investigated using a Matsuura LUMEX Avance-25 system that integrates metal additive manufacturing using laser powder bed fusion (LPBF) processing with high-speed machining. A series of benchmarking coupons were additively printed at four different power levels (160 W, $240 \mathrm{~W}, 320 \mathrm{~W}, 380 \mathrm{~W}$ ) and with the integration of sequential machining passes after every 10 deposited layers, as well as final finishing of selected surfaces. Using non-contact three-dimensional laser scanning, inspection of the final geometry of the $18 \mathrm{Ni}-300$ maraging steel coupons against the computer-aided design (CAD) model indicated the good capability of the Matsuura LUMEX Avance25 system for net-shape manufacturing. Linear and areal roughness measurements of the surfaces showed average $\mathrm{Ra} / \mathrm{Sa}$ values of $8.02-14.64 \mu \mathrm{m}$ for the as-printed walls versus $0.32-0.80 \mu \mathrm{m}$ for the machined walls/faces. Using Archimedes and helium ( $\mathrm{He}$ ) gas pycnometry methods, the part density was measured to be lowest for coupons produced at $160 \mathrm{~W}$ (relative density of 93.3-98.5\%) relative to those at high power levels of $240 \mathrm{~W}$ to $380 \mathrm{~W}$ (relative density of 99.0-99.8\%). This finding agreed well with the results of the porosity size distribution determined through X-ray micro-computed tomography $(\mu \mathrm{CT})$. Evaluation of the static tensile properties indicated that the coupons manufactured at the lowest power of $160 \mathrm{~W}$ were $~ 30 \%$ lower in strength, $24 \%$ lower in stiffness, and more than $80 \%$ lower in ductility relative to higher power conditions (240 W to $380 \mathrm{~W}$ ) due to the lower density at $160 \mathrm{~W}$.
\end{abstract}

Keywords: hybrid manufacturing; laser powder bed fusion; maraging steel; density; surface quality; X-ray micro-computed tomography; microstructure; hardness; tensile properties; fractography

\section{Introduction}

Since being introduced in the early 1960s, the $18 \%$ nickel (18Ni) family of maraging steels remains important to the aerospace, defense, nuclear, as well as the tool and die industries due to their unique combination of different properties, including high strength, high hardness, excellent toughness, ease of welding, good machinability, and dimensional stability [1,2]. Furthermore, the low carbon content of $18 \mathrm{Ni}$ maraging steels develops (on cooling from elevated temperatures) a soft martensitic matrix that is mostly free from interstitial alloying elements and less prone to cracking during solidification from the liquid state; thus, this makes these steels appropriately suited for processing additively [3]. Considering the relatively high cost of nickel and microalloy additions to these steels, the circular economy possible with additive manufacturing (AM) provides material savings, inasmuch 
as the recycling of the $18 \mathrm{Ni}$ maraging steel powder promises [4]. Additive processing of $18 \mathrm{Ni}$ maraging steels is also of avid interest for architecting conformal channels $[5,6]$ for transpiration cooling, so as to mitigate partial reversion of martensite into austenite [7], as well as the accompanying strength losses and geometric instabilities [5,8-11], especially during cyclic/extended service at elevated temperatures. To date, this improved cooling efficiency - which was made possible in maraging steel parts designed with novel conformal channels and fabricated using metal AM technologies (particularly with LPBF processing) - has reduced process cycle times in injection molding [12] of plastics and, more recently, in high-pressure die casting of metals [13], where the pressures and temperatures are significantly greater.

However, the surface accuracy and areal roughness directly after AM using LPBF processes remain far below $[14,15]$ industrial requirements of maraging steel parts used in applications needing tight geometric tolerances, machined finishes, and/or fatigue strength. Thus, post-processing with a machining step after AM is necessary for excess material removal for suitable conformance to the part geometry and to meet the surface roughness requirements, typically between $0.2-0.5 \mu \mathrm{m}$ [16]. Undertaken separately, serial additivesubtractive production of high-complexity parts faces challenges for suitable referencing, indexing, and programming that can obliterate the cost benefits in the break-even analysis for AM. Unsurprisingly, recent developments have intensified in hybrid manufacturing that integrates LPBF AM and conventional subtractive processing within a single work envelope to enable synergies from both technologies [17].

In such hybrid additive/subtractive manufacturing systems, the part is built layerby-layer using LPBF, followed by machining to remove excessive material and smooth "stair-stepping effects" on layer-manufactured surfaces to improve the surface quality. Machining is either performed after each layer or a number of layers with the objective of enabling a high-quality part with the required net-shape/geometry, dimensional tolerances, and surface finish. The synergies of hybridization have distinctive/disruptive advantages for building intricate/complex geometries with internal architected features (such as conformal channels for cooling and/or cellular structures for permeability) and machining (within the geometric limitations of the toolpath) high-quality surface finishes with tight dimensional tolerances in a single setup (in-envelope process) [18].

Development of this hybrid manufacturing process, however, requires a detailed understanding of the effect of build process parameters and interactions, as well as the synergies of the additive and subtractive sequences that affect the microstructure, defects, residual stresses, distortion, dimensional integrity of machined surfaces, and mechanical properties of the final part. To date, many LPBF research studies have been performed using stand-alone AM systems to examine either process parameter optimization or mechanical properties of maraging steels. For $18 \mathrm{Ni}-300$ maraging steel, Casalino et al. [19] investigated the influence of process parameters on density, while Bai et al. [20] conducted experiments on parametric optimization to avoid vaporization and spatter. In addition, Suryawanshi et al. [21] investigated the anisotropic behavior of as-printed and solution-aged samples. Despite the relative newness of hybrid (LPBF) manufacturing, state-of-the-art research studies have also provided some early understandings of the separate influences of the additive-subtractive processes. For example, Tamura et al. [22] reported on the anisotropic milling forces during hybrid (LPBF) manufacturing of maraging steels, while Sugino et al. [23] studied the gas permeability of lattice structures in maraging steel permeable molds. On the additive end, Enemuoh et al. [24] measured the density, hardness, and tensile properties of $18 \mathrm{Ni}-300$ maraging steel samples built using hybrid (LPBF) manufacturing with one parameter set that was not disclosed, and is thus difficult to link to the process. The research work of Wüst et al. [25] and Mutua et al. [26] involved the design of experiment approach to optimize the parameters for surface finish and densification, respectively. However, the optimal combination of additive parameters identified by Wüst et al. [25] for minimizing the as-printed surface roughness was at a significantly higher energy density (ED) $\left(\sim 112 \mathrm{~J} / \mathrm{mm}^{3}\right)$ than the optimal condition reported 
for densification $\left(71 \mathrm{~J} / \mathrm{mm}^{3}\right)$ by Mutua et al. [26]. More perplexing are the lower as-printed tensile properties, as reported by Mutua et al. [26], after optimizing the hybrid (LPBF) manufacturing process for $18 \mathrm{Ni}-300$ maraging steel, which gave an ultimate tensile strength (UTS) of $1125 \mathrm{MPa}$ with a percent elongation (EL) of $\sim 8.2 \%$ in the vertical direction, relative to that reported by Enemuoh et al. [24] of $1205 \mathrm{MPa}$ and 14\%, respectively, for the same orientation, but using undisclosed process conditions.

Based on these previous preliminary findings, the characteristics and performance of $18 \mathrm{Ni}-300$ maraging steel are sensitive to the hybrid (LPBF) manufacturing process that require a systemic study for parametric optimization, as well as interrelating to the porosity, macro/microstructure, mechanical properties, and fracture. Therefore, the research priorities in this present study were defined to systematically examine the effect of parametric changes on hybrid (LPBF) manufacturing of $18 \mathrm{Ni}-300$ maraging steel with a Matsuura LUMEX Avance-25 additive-subtractive system. Rectangular prismatic-shaped coupons were printed-to more closely represent mold/die structures (as opposed to directly printed tensile samples)—and examined comprehensively in the as-printed (non-aged) condition for geometric conformity, surface finish, density, porosity, macro/microstructure, hardness, tensile properties, and fracture behavior, so as to develop the process-structureproperty linkages.

\section{Experimental Procedure}

The 18Ni-300 maraging steel (or X3NiCoMoTi18-9-5) powder used in this work was supplied by Matsuura (St. Paul, MN, USA) with a chemical composition (wt.\%), as shown in Table 1.

Table 1. Chemical composition (wt.\%) of $18 \mathrm{Ni}-300$ maraging steel powder.

\begin{tabular}{cc}
\hline Element & Composition \\
\hline $\mathrm{C}$, & $0.01 \mathrm{wt} \%$ \\
$\mathrm{Ni}$, & $17.9 \mathrm{wt.} \%$ \\
$\mathrm{Mn}$, & $0.06 \mathrm{wt.} \%$ \\
$\mathrm{Cr}$ & $0.2 \mathrm{wt.} \%$ \\
$\mathrm{Mo}$ & $5.0 \mathrm{wt.} \%$ \\
$\mathrm{Si}$ & $0.08 \mathrm{wt.} \%$ \\
$\mathrm{P}$ & $0.008 \mathrm{wt} \%$ \\
$\mathrm{~S}$ & $0.006 \mathrm{wt.} \%$ \\
$\mathrm{Co}$ & $8.9 \mathrm{wt.} \%$ \\
$\mathrm{Ti}$ & $0.8 \mathrm{wt.} \%$ \\
$\mathrm{Al}$ & $0.11 \mathrm{wt} \%$ \\
$\mathrm{O}$ & $0.04 \mathrm{ppm}$ \\
$\mathrm{N}$ & $0.02 \mathrm{ppm}$ \\
\hline
\end{tabular}

Measurement of the particle size distribution of the starting powder was performed using a Horiba laser scattering particle size analyzer LA-920 (Minami-ku, Kyoto, Japan) and showed a D10 (10th percentile) of $23 \mu \mathrm{m}$, a D50 (median) of $34 \mu \mathrm{m}$, and a D90 (90th percentile) of $52 \mu \mathrm{m}$. The surface morphology of the powder, analyzed using a Hitachi SU3500 (Fukuoka-shi, Fukuoka, Japan) scanning electron microscope (SEM), revealed predominantly spherical particles with smooth surfaces, regular morphologies, and a few satellites. A limited number of elongated and irregular particles was also present, as shown in Figure 1a. 


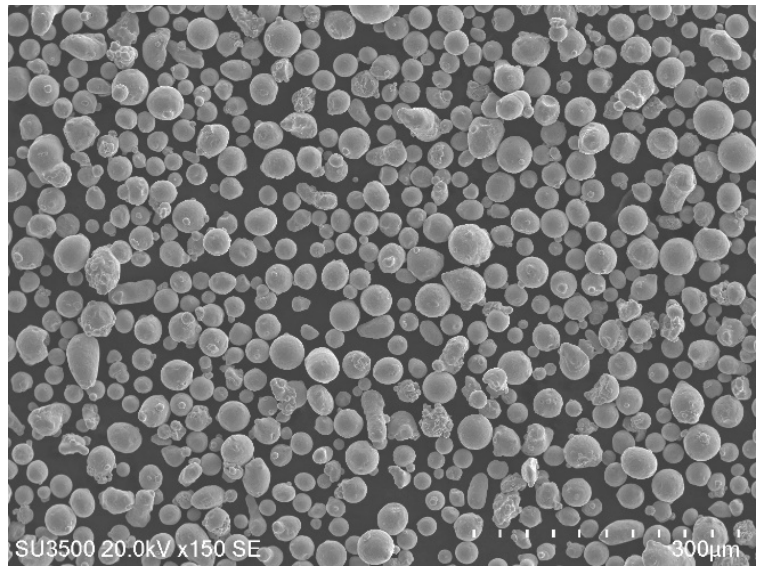

(a)

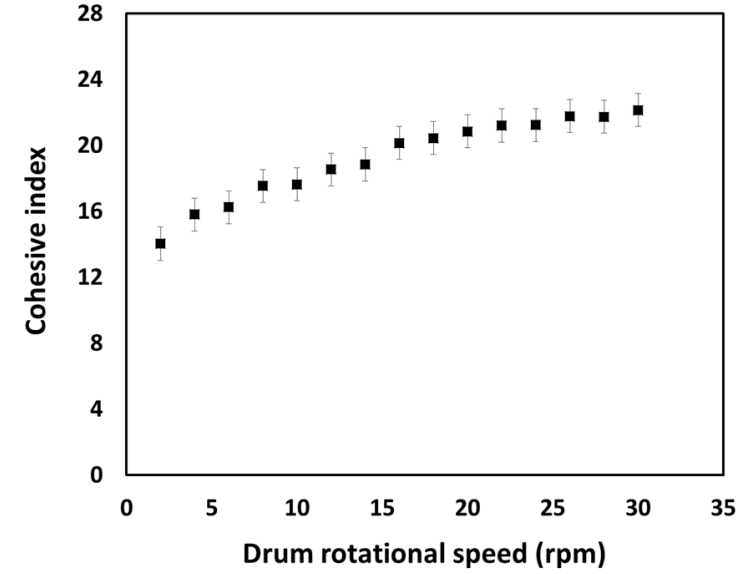

(b)

Figure 1. (a) SEM image showing the powder morphology, and (b) the cohesive index of $18 \mathrm{Ni}-300$ maraging steel powder versus the drum rotation speed.

The static flow behavior of the powder was measured using Hall and Carney flowmeter funnels, according to ASTM B213 and ASTM B964 standards [27,28], respectively. The flowability per $50 \mathrm{~g}$ of powder through the Hall and Carney funnels was $23 \mathrm{~s}$ and $3 \mathrm{~s}$, respectively. The apparent density (AD) of the powder was measured according to ASTM B212 and ASTM B417 standards [29,30], and was found to be $4.28 \mathrm{~g} / \mathrm{cm}^{3}$ and $4.31 \mathrm{~g} / \mathrm{cm}^{3}$ with the Hall and Carney funnels, respectively. The static angle of repose (AOR), calculated using an image analysis software (Image J) from the conical pile-up of powders, was statistically similar to $38^{\circ}$ and, based on Carr's classification of powder flowability, was sufficient for promoting good powder spreading during printing for minimizing defects [31].

The cohesive index of the powder particles was measured using a Granudrum ${ }^{\circledR}$ rotating drum system with angular velocities ranging from 2-30 rpm, and 40 images of the drum were captured at an interval of $1 \mathrm{frame} / \mathrm{s}$ for each revolution per minute. The average location of the air/powder interface and the fluctuations from the average interface at each angular velocity were computed by the built-in GranuDrum ${ }^{\circledR}$ software from which the cohesive index was calculated. As depicted in Figure 1b, the measured data show a relatively low cohesive index. This current value is indicative of good powder flowability based on previously reported findings [32] (i.e., powders with a cohesive index below 24 exhibit free-flowing behavior and result in a uniform and homogenous layer during powder spreading in the LPBF process).

Hybrid manufacturing with the $18 \mathrm{Ni}-300$ maraging steel powder was undertaken in a Matsuura LUMEX Avance-25 system via the LPBF technology integrated with highspeed milling to fabricate 4 rectangular prismatic-shaped coupons with dimensions of $75 \mathrm{~mm}(X) \times 25 \mathrm{~mm}(\mathrm{Y}) \times 25 \mathrm{~mm}(\mathrm{Z})$ on a 4140 steel build plate with dimensions of $125 \mathrm{~mm}(\mathrm{X}) \times 175 \mathrm{~mm}(\mathrm{Y}) \times 30 \mathrm{~mm}(\mathrm{Z})$. The build plate was demagnetized using a surface demagnetizer (Electro-Matic model A13-1, R. B. Annis, ELMATCO, Chicago, IL, USA) to achieve a suitable magnetic field of $<0.2$ Gauss, and was then fixed onto the table of the Matsuura LUMEX Avance-25 system. During the hybrid (LPBF) manufacturing process, the build plate temperature was set to $50^{\circ} \mathrm{C}$, and the working chamber was filled with nitrogen gas (consisting of no more than $3 \%$ oxygen) to prevent oxidization of the molten pool during laser melting. A uni-directional laser scanning strategy with a $90^{\circ}$ rotation after every layer was used for LPBF printing at 4 different powers $(\mathrm{P})-160 \mathrm{~W}, 240 \mathrm{~W}, 320 \mathrm{~W}$, and $380 \mathrm{~W}$-which were used for both the rastering/infill and contouring passes (one of each per layer). The parameters used in the experimental design are listed in Table 2 for the laser scan speed (v), spot diameter (d), hatch distance (h), and layer thickness (t). After LPBF printing of 10 successive layers, milling was performed at a feed rate of $2000 \mathrm{~mm} / \mathrm{min}$ with a $0.1-\mathrm{mm}$ radial depth of cut for the vertical side-walls and $4 \mathrm{~mm}$ for the horizontal top surface, based on the manufacturer's recommended setting. 
Table 2. Experimental parameters for hybrid (LPBF) manufacturing of the $18 \mathrm{Ni}-300$ maraging steel.

\begin{tabular}{|c|c|c|c|c|c|c|}
\hline Parameters & $\mathrm{h}(\mu \mathrm{m})$ & $t(\mu \mathrm{m})$ & $\mathrm{d}(\mu \mathrm{m})$ & $\mathrm{v}(\mathrm{mm} / \mathrm{s})$ & $P(W)$ & $\operatorname{ED}\left(\mathrm{J} / \mathrm{mm}^{3}\right)$ \\
\hline \multirow{4}{*}{ Infill } & \multirow{4}{*}{120} & \multirow{4}{*}{50} & \multirow{4}{*}{200} & \multirow{4}{*}{700} & 160 & 38.1 \\
\hline & & & & & 240 & 57.1 \\
\hline & & & & & 320 & 76.2 \\
\hline & & & & & 380 & 90.5 \\
\hline \multirow{4}{*}{ Contour } & \multirow{4}{*}{120} & \multirow{4}{*}{50} & \multirow{4}{*}{200} & \multirow{4}{*}{1400} & 160 & 19.0 \\
\hline & & & & & 240 & 28.6 \\
\hline & & & & & 320 & 38.1 \\
\hline & & & & & 380 & 45.2 \\
\hline
\end{tabular}

It is noteworthy that the power levels of $160 \mathrm{~W}, 240 \mathrm{~W}, 320 \mathrm{~W}$, and $380 \mathrm{~W}$ in this study correspond to infill ED values of $38.1 \mathrm{~J} / \mathrm{mm}^{3}, 57.1 \mathrm{~J} / \mathrm{mm}^{3}, 76.2 \mathrm{~J} / \mathrm{mm}^{3}$, and $90.5 \mathrm{~J} / \mathrm{mm}^{3}$, and contour ED values of $19.0 \mathrm{~J} / \mathrm{mm}^{3}, 28.6 \mathrm{~J} / \mathrm{mm}^{3}, 38.1 \mathrm{~J} / \mathrm{mm}^{3}$, and $45.2 \mathrm{~J} / \mathrm{mm}^{3}$, respectively, as shown in Table 2 and calculated using Equation (1):

$$
\mathrm{ED}=\mathrm{P} /(\mathrm{vht})
$$

The geometry after printing of the 4 rectangular prismatic-shaped coupons (still attached to build plate), as shown in Figure 2a, was inspected using an ATOS Core optical three-dimensional (3D) scanning system (GOM-Trilion Quality Systems, King of Prussia, PA, USA) and the measured dimensions were compared to the 3D CAD model to assess the conformity/accuracy. Then, electro-discharge machining (EDM) (FANUC Robocut C400iB, Oshino-mura, Yamanashi, Japan) with a $0.2-\mathrm{mm}$ diameter brass wire was used to separate the coupons from the build plate. The surface quality of coupons on both as-printed and machined faces was evaluated using a portable Mitutoyo Surftest SJ-210 4MN profilometer and a Keyence VK-X250 3D laser scanning confocal microscope to measure the linear roughness parameters (arithmetic mean height $(\mathrm{Ra})$, root mean square height $(\mathrm{Rq})$, and maximum height (Rz)), as well as surface roughness parameters (Sa, Sq, and Sz, that are areal counterparts of $\mathrm{Ra}, \mathrm{Rq}$, and $\mathrm{Rz}$ ), respectively.

Each coupon was then sectioned first along the $\mathrm{YZ}$ plane into two halves- $\mathrm{A}$ and $\mathrm{B}$ (as shown in Figure 2b). Section A was used to extract specimens for density, $X$-ray $\mu C T$, and tensile property measurements, while section $B$ was used to extract specimens for metallographic and hardness evaluations. From section A, 3 specimens were extracted by EDM through the thickness in the build direction (BD) of each coupon $(160 \mathrm{~W}, 240 \mathrm{~W}$, $320 \mathrm{~W}$, and $380 \mathrm{~W}$ ), as shown in Figure $2 \mathrm{~b}$, and then machined/milled to the geometry of a standard sub-size tensile specimen (as shown in Figure 2c), according to the principles given in ASTM E8M [33] for a gage length of $25 \mathrm{~mm}$. After machining and before tensile testing, these test specimens were examined for porosity and density using 3 methods: Archimedes [34], helium ( $\mathrm{He})$ gas pycnometry [35], and X-ray $\mu \mathrm{CT}$. Density measurements using the Archimedes and He gas pycnometry methods were undertaken with an AND BM-500 density measurement kit and an Anton Paar Ultrapyc 5000 system, respectively. For the calculation of relative density, a theoretical value of $8.1 \mathrm{~g} / \mathrm{cm}^{3}$ was used for $18 \mathrm{Ni}-300$ maraging steel [1]. X-ray $\mu \mathrm{CT}$ was performed on the gage length of the tensile specimens to evaluate the porosity distribution and pore size using a Nikon HMXST 225 system (Nikon Metrology Inc., USA) equipped with a Perkin-Elmer 1621AN CsI $(2000 \times 2000$ pixels, $40 \mathrm{~cm} \times 40 \mathrm{~cm}, 200 \mu \mathrm{m} /$ pixel) detector panel (as shown in Figure 2d). The scans were undertaken at two magnification levels: first, at a magnification level of 10.9X which allowed for a complete visualization of the gage length and gave a voxel size of $18.4 \mu \mathrm{m}$; and second, at a higher magnification of $46 \mathrm{X}$ which gave a voxel size of $4.4 \mu \mathrm{m}$. The X-ray $\mu \mathrm{CT}$ was operated at a voltage of $120 \mathrm{kV}$, a current of $58 \mu \mathrm{A}$ with a $0.25-\mathrm{mm} \mathrm{Ag}$ filter, and an exposure time of $1000 \mathrm{~ms}$. For image analysis, Dragonfly software was utilized for 3D reconstruction to analyze the volume and size distribution of the pores using manual segmentation. 


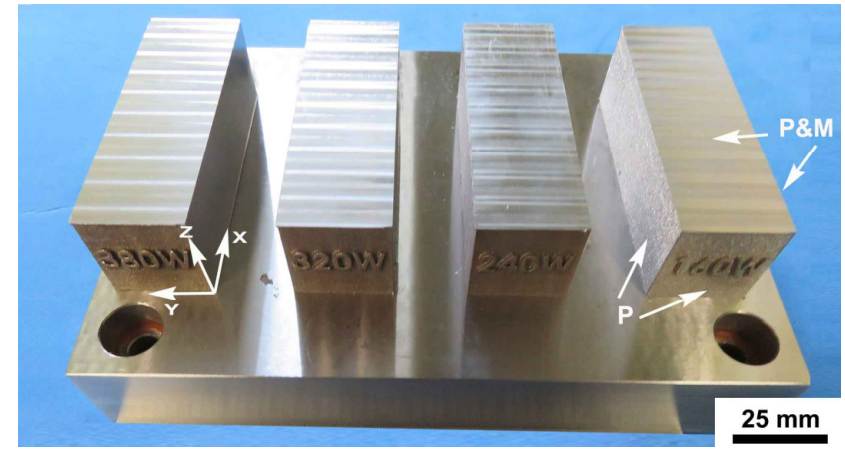

(a)
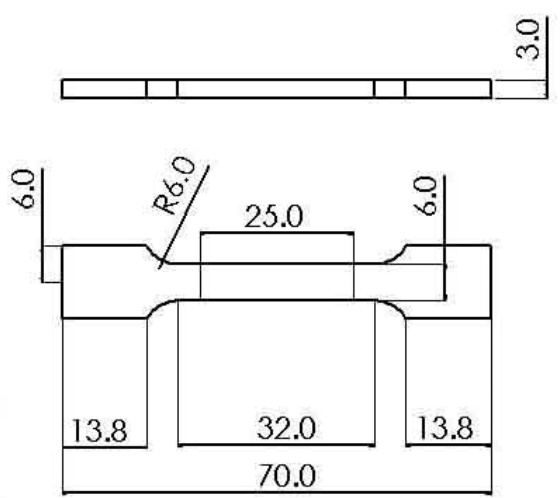

OBD

(c)

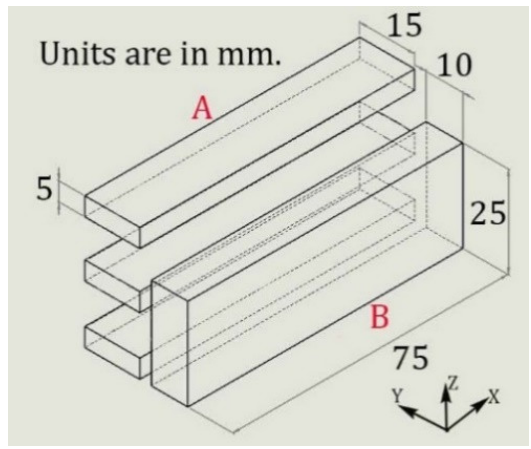

(b)

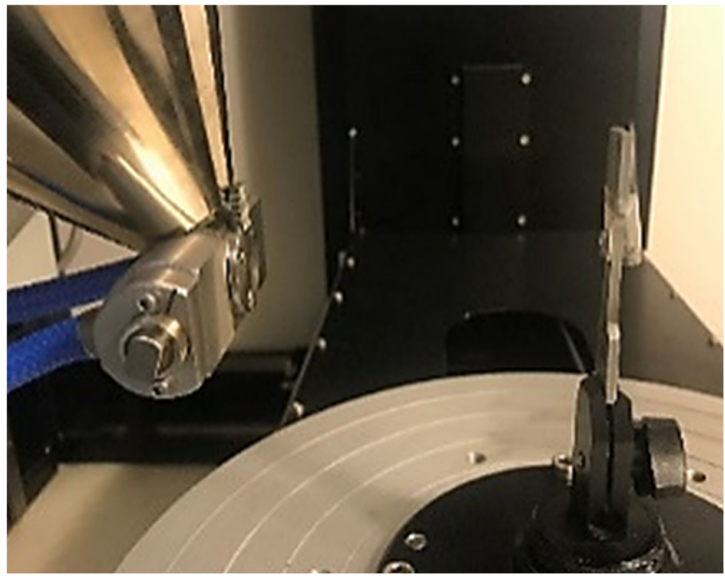

(d)

Figure 2. (a) Coupons manufactured by hybrid (LPBF) manufacturing showing the as-printed (P) as well as printed and machined (P\&M) surfaces, (b) extraction scheme of tensile specimens from each coupon, (c) geometry of each tensile specimen, and (d) X-ray $\mu \mathrm{CT}$ set up for inspecting each tensile specimen.

Tensile testing of the 12 specimens-3 per each power level $(160 \mathrm{~W}, 240 \mathrm{~W}, 320 \mathrm{~W}$, and $380 \mathrm{~W}$ ), which were extracted from the top, middle, and bottom of section $\mathrm{A}$ in the 4 asprinted coupons-was performed under ambient conditions using a 250-kN MTS testing frame integrated with a laser extensometer. Tensile tests were conducted until rupture using displacement control at a rate of $0.4 \mathrm{~mm} / \mathrm{min}$. The tensile properties evaluated in this work included the yield strength or $0.2 \%$ proof stress (YS), UTS, EL, and elastic modulus (E). The fracture surfaces of the specimens after tensile testing were observed using a SEM at $15 \mathrm{keV}$ to examine the failure characteristics of the $18 \mathrm{Ni}-300$ maraging steel in the presence of different pore structures (interconnected, isolated).

On the other hand, the section B (as shown in Figure $2 b$ ) portion of the 4 as-printed coupons $(160 \mathrm{~W}, 240 \mathrm{~W}, 320 \mathrm{~W}$, and $380 \mathrm{~W})$ was utilized for metallographic and hardness evaluations. To examine the $3 \mathrm{D}$ characteristics of the $18 \mathrm{Ni}-300$ maraging steel macro/microstructures, 3 orthogonal planes $(X-Y, Y-Z, X-Z)$ were extracted for each process condition $(160 \mathrm{~W}, 240 \mathrm{~W}, 320 \mathrm{~W}$, and $380 \mathrm{~W})$ and prepared for metallography by cold mounting, followed by automated grinding and polishing steps, as described in [36], to obtain a $0.04-\mu \mathrm{m}$ finish. To reveal the general microstructure, the specimens were chemically etched at ambient temperature by immersing in a $2 \%$ Nital (nitric acid in ethanol) solution for $2 \mathrm{~min}$.

Two test methods were used to measure the hardness of the specimens: Rockwell and Vickers, according to ASTM standard specifications, as given in [37,38], respectively. To measure the bulk hardness, Rockwell testing was conducted using a diamond rounded-tip cone indenter (ground at $120^{\circ}$ ) with a diameter of $0.2 \mathrm{~mm}$ and a minor load of $10 \mathrm{~kg}$, followed by a major load of $150 \mathrm{~kg}$, in accordance with guidelines for the C-scale typically used for steels. At least 5 Rockwell $C$ hardness (HRC) measurements were carried out 
for each specimen condition ( $160 \mathrm{~W}, 240 \mathrm{~W}, 320 \mathrm{~W}$, and $380 \mathrm{~W})$. Vickers microhardness (HV) measurements were performed on the specimens prepared with a polished (mirror finished) surface using a Struers DuraScan 80 hardness tester (Ballerup, Denmark) with a fully automatic cycle [39]. The reported Vickers hardness distribution across the specimen cross-sections was determined from the average of 3 measurements for each point with a load of $500 \mathrm{~g}$, an indent spacing of $0.8 \mathrm{~mm}$, and a dwell period of $15 \mathrm{~s}$.

\section{Results and Data Analysis}

\subsection{Surface Quality}

The high thermal gradients and cyclic thermal expansion/shrinkage, occurring in $18 \mathrm{Ni}-300$ maraging steel parts printed using LPBF AM, are a source of plastic strains that can affect the distribution of internal stresses (also known as residual stresses) and result in distortions that may render the part out of tolerance with respect to the initial CAD geometry. Thus, the 4 rectangular prismatic-shaped coupons, still attached to the build plate after hybrid manufacturing (Figure 2a), were inspected using an ATOS Core Optical 3D scanning system to evaluate the distortions/deviations in their geometry relative to the CAD model using a best-fit algorithm. For the 4 coupons fabricated by hybrid manufacturing, Figure 3 describes the inspection results through a contour map with a color scale selected for the range of $-0.3 \mathrm{~mm}$ to $0.3 \mathrm{~mm}$ in distortion/deviation. Overall, the deviations between the geometry of the coupons and the CAD model were higher for the as-printed surfaces (Figure 3a), ranging from about $30 \mu \mathrm{m}$ to $160 \mu \mathrm{m}$. After machining, the deviations (Figure $3 \mathrm{~b}$ ) could be reduced to values between $10 \mu \mathrm{m}$ and $110 \mu \mathrm{m}$, indicating high accuracy in the final geometry. It is noteworthy that the highest deviations were noticed for the as-printed surfaces built at $380 \mathrm{~W}$, which was at the highest infill ED of $90.5 \mathrm{~J} / \mathrm{mm}^{3}$ used in the present study. Previously, thermal simulation of the LPBF process has indicated high sensitivity of the part dimensions to the process parameters affecting the ED [40], which reasonably explains the current findings of lower dimensional precision/accuracy for the $380 \mathrm{~W}$ condition.

a

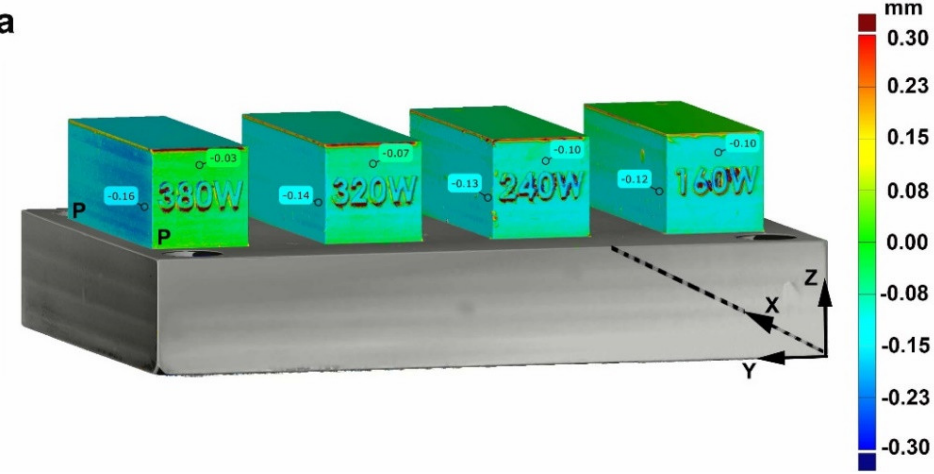

b

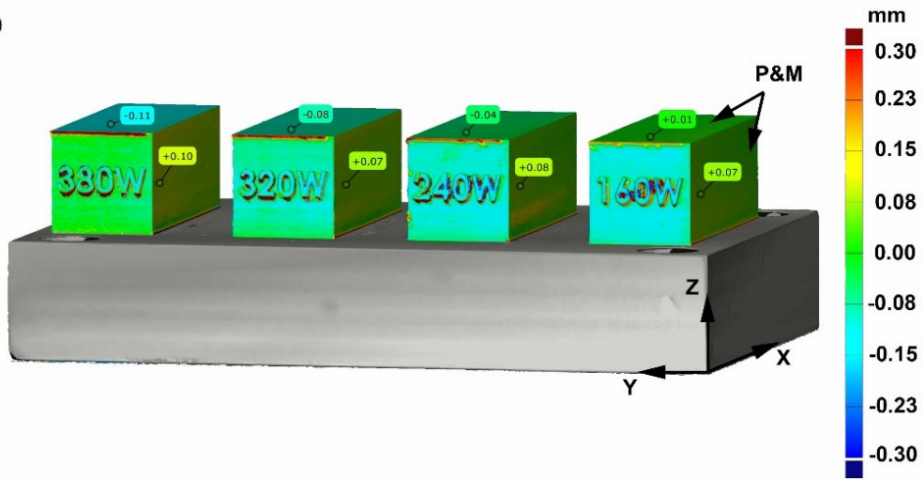

Figure 3. Contour plots showing the out-of-plane deviations from the CAD model of the 4 coupons manufactured at different power levels $(\mathbf{a})$ as-printed $(\mathrm{P})$ surfaces and $(\mathbf{b})$ printed and machined (P\&M) surfaces. 
To understand the surface quality of the $18 \mathrm{Ni}-300$ maraging steel produced by hybrid (LPBF) manufacturing, the average values of the different roughness parameters were measured on linear profiles and surface areas of the as-printed and machined faces of the 4 coupons, as given in Table 3. It is noteworthy that, previously, Sa and Sq were reported to be suitable areal parameters for describing the surfaces produced in LPBF AM applications [41]; however, in the current study, linear profile roughness parameters were also examined, as these remain predominant in industrial manufacturing sites for surface quality inspections due to current international standards being based on two-dimensional (2D) measurement and characterization [42].

Table 3. Roughness parameters measured on different walls/faces of coupons produced using hybrid (LPBF) manufacturing at different power levels.

\begin{tabular}{|c|c|c|c|c|c|c|c|c|c|}
\hline \multirow{2}{*}{$\begin{array}{l}\text { Condition/ } \\
\text { Face }\end{array}$} & \multirow{2}{*}{ Power (W) } & \multicolumn{2}{|c|}{$\mathrm{ED}\left(\mathrm{J} / \mathrm{mm}^{3}\right)$} & \multicolumn{3}{|c|}{ Linear $(\mu \mathrm{m})$} & \multicolumn{3}{|c|}{ Areal $(\mu \mathrm{m})$} \\
\hline & & Infill & Contour & $\mathbf{R a}$ & $\mathbf{R q}$ & $\mathbf{R z}$ & Sa & $\mathrm{Sq}$ & $\mathrm{Sz}$ \\
\hline \multirow{4}{*}{$\begin{array}{l}\text { As-printed } \\
\text { side-walls }\end{array}$} & 160 & 38.1 & 19.0 & 10.15 & 12.82 & 56.74 & 10.16 & 13.40 & 109.71 \\
\hline & 240 & 57.1 & 28.6 & 9.54 & 11.95 & 52.89 & 8.02 & 10.28 & 46.40 \\
\hline & 320 & 76.2 & 38.1 & 9.67 & 12.14 & 52.95 & 11.26 & 14.76 & 114.39 \\
\hline & 380 & 90.5 & 45.2 & 12.26 & 15.24 & 67.13 & 14.64 & 18.83 & 128.79 \\
\hline \multirow{4}{*}{$\begin{array}{l}\text { Machined } \\
\text { side-walls }\end{array}$} & 160 & 38.1 & 19.0 & 0.32 & 0.39 & 2.11 & 0.43 & 0.54 & 4.55 \\
\hline & 240 & 57.1 & 28.6 & 0.45 & 0.54 & 2.54 & 0.57 & 0.71 & 5.93 \\
\hline & 320 & 76.2 & 38.1 & 0.65 & 0.80 & 3.85 & 0.80 & 0.96 & 6.02 \\
\hline & 380 & 90.5 & 45.2 & 0.56 & 0.69 & 3.44 & 0.54 & 0.68 & 5.13 \\
\hline \multirow{4}{*}{$\begin{array}{l}\text { Machined } \\
\text { top-face }\end{array}$} & 160 & 38.1 & 19.0 & 0.38 & 0.46 & 2.21 & 0.51 & 0.61 & 3.63 \\
\hline & 240 & 57.1 & 28.6 & 0.42 & 0.50 & 2.18 & 0.47 & 0.56 & 3.64 \\
\hline & 320 & 76.2 & 38.1 & 0.43 & 0.51 & 2.21 & 0.54 & 0.64 & 4.00 \\
\hline & 380 & 90.5 & 45.2 & 0.45 & 0.54 & 2.46 & 0.59 & 0.70 & 7.54 \\
\hline
\end{tabular}

On the as-printed vertical side-walls, the lowest and highest values for the linear and areal surface roughness parameters ( $\mathrm{Ra} / \mathrm{Sa}, \mathrm{Rq} / \mathrm{Sq}$ and $\mathrm{Rz} / \mathrm{Sz}$ ) were measured for the $240 \mathrm{~W}$ and $380 \mathrm{~W}$ conditions, respectively. Furthermore, reducing the power level from $240 \mathrm{~W}$ to $160 \mathrm{~W}$ or increasing it from $240 \mathrm{~W}$ to $320 \mathrm{~W}$ increased the linear and areal surface roughness parameters, and suggests a balanced/optimized power level at $240 \mathrm{~W}$, vis-à-vis the surface finish. Overall, for the vertical side-wall surfaces printed at the four power levels, the measured $\mathrm{Ra}$ (ranging from 9.54-12.26 $\mu \mathrm{m}$ ) and Sa (ranging from 8.02-14.64 $\mu \mathrm{m}$ ) data were in good agreement with the manufacturer's reference Sa values of $6.5 \mu \mathrm{m}$ to $15 \mu \mathrm{m}$ that varied for $18 \mathrm{Ni}-300$ maraging steel depending on the applied processing variables, as reported in [25]. In particular, the source of roughness on the vertical sidewalls built using LPBF technology has been attributed to the layered nature of the process, which forms stair-step delineations that depend strongly on the layer thickness and the process parameters that influence it (e.g., P, v, h, etc.), as well as the orientation of the surface relative to BD $[16,43,44]$. Thus, the surface roughness can be improved directly by decreasing the layer thickness or through the several interlinked factors in the LPBF process (as mentioned above). In case of the latter, inappropriate heat input for contour passes during LPBF processing has been linked to higher roughness due to melt pool instabilities manifesting into unusual surface irregularities $[45,46]$. Specifically, too low values for the contour ED lead to an unstable deposition of scan tracks that exhibit a lack of melting and balling, which, in turn, increase the surface roughness [47]. By contrast, too high ED values for the contour passes cause evaporation and lead to high roughness [48]. Previously, Mutua et al. [26] examined 18Ni-300 maraging steel produced using the Matsuura LUMEX Avance-25 system and reported a minimum Ra of $35 \mu \mathrm{m}$ for an « optimal » infill ED setting of $71.4 \mathrm{~J} / \mathrm{mm}^{3}$ (using a P of $300 \mathrm{~W}$, spot diameter of $200 \mu \mathrm{m}$, h of $120 \mu \mathrm{m}, \mathrm{v}$ of $700 \mathrm{~mm} / \mathrm{s}$ and $t$ of $50 \mu \mathrm{m})$, above and below which the surface roughness was higher $(50 \mu \mathrm{m}-70 \mu \mathrm{m})$. Though the absolute Ra values reported by Mutua et al. [26] are considerably higher than the manufacturer's reference values, as well as those determined in this work, the trends 
remain similar. This reasonably supports the findings for the $240 \mathrm{~W}$ power level (or contour ED of $28.6 \mathrm{~J} / \mathrm{mm}^{3}$ ) condition that exhibited lower roughness parameters compared to the lowest setting at $160 \mathrm{~W}$ (contour ED of $19.0 \mathrm{~J} / \mathrm{mm}^{3}$ ) and/or higher settings at $320 \mathrm{~W}$ (contour ED of $38.1 \mathrm{~J} / \mathrm{mm}^{3}$ ) and $380 \mathrm{~W}$ (contour ED of $45.2 \mathrm{~J} / \mathrm{mm}^{3}$ ), which will be discussed below in relation to the changes in density and porosity characteristics.

In case of the machined surfaces, the Ra and Sa were typically more than an order of magnitude lower than the as-printed surfaces. On the vertical side-wall surfaces, the $\mathrm{Ra}$ and Sa values ranged from $0.32 \mu \mathrm{m}$ to $0.65 \mu \mathrm{m}$ and $0.43 \mu \mathrm{m}$ to $0.8 \mu \mathrm{m}$, respectively. The $\mathrm{Ra}$ and Sa values on the horizontal top-face surfaces were comparable, ranging from $0.38 \mu \mathrm{m}$ to $0.45 \mu \mathrm{m}$ and $0.47 \mu \mathrm{m}$ to $0.59 \mu \mathrm{m}$, respectively. These findings offer strong evidence of the high efficiency and process flexibility possible with the hybrid (LPBF) manufacturing technology; the superior capacity of the milling process to unequivocally improve the surface finish renders greater flexibility to optimize the LPBF process for material performance requirements. Overall, the surface roughness parameters determined in the present study for the machined surfaces of $18 \mathrm{Ni}-300$ maraging steel are in good agreement with the findings of Wüst et al. [25], who reported Ra and/or Sa values that depended on the milling parameters and ranged from $0.292 \mu \mathrm{m}$ to $0.469 \mu \mathrm{m}$ for vertical surfaces and $0.763 \mu \mathrm{m}$ to $1.173 \mu \mathrm{m}$ on horizontal surfaces.

\subsection{Porosity and Density Characteristics}

The porosity and density were characterized by three methods: X-ray $\mu \mathrm{CT}$, Archimedes, and gas pycnometry methods. First, the pore characteristics were explored by $X$-ray $\mu C T$, as shown in Figure 4. From Figure $4 a$, it is apparent that LPBF processing at a power of $160 \mathrm{~W}\left(\mathrm{ED}\right.$ of $38.1 \mathrm{~J} / \mathrm{mm}^{3}$ ) resulted in numerous remnant pores (i.e., dark areas in X-ray image) that were large, irregularly-shaped, interconnected, and preferentially distributed in the interlayer regions. The occurrence of such pores can be attributed to the insufficient infill ED at $160 \mathrm{~W}$ that prevented adequate melting of the powder and led to the unstable/irregular deposition of scan tracks with lack of fusion defects. By increasing the power level to $240 \mathrm{~W}$, the higher infill ED of $57.1 \mathrm{~J} / \mathrm{mm}^{3}$ improved densification of the powder during LPBF processing, as evidenced in Figure $4 \mathrm{~b}$ by the considerable reduction in the number and size of pores, which were mostly regular-in-shape (nearly spherical), closed, and less than $50 \mu \mathrm{m}$ in size (as highlighted in the inset images). The X-ray $\mu C T$ scan of the 18Ni-300 maraging steel fabricated at a power level of $320 \mathrm{~W}$ (Figure 4c) appeared to be relatively similar to that observed for the $240 \mathrm{~W}$ condition, and the isolated pores observed were also smaller than $50 \mu \mathrm{m}$ in size. At the maximum power of $380 \mathrm{~W}$ (and infill ED of $90.5 \mathrm{~J} / \mathrm{mm}^{3}$ ) used in this study, coarsening of the pores was obvious-especially in the inset images displayed in Figure 4d-with typical sizes ranging from $50 \mu \mathrm{m}$ to $100 \mu \mathrm{m}$ (or slightly higher).

To understand the size distribution and volume of pores, the high magnification X-ray $\mu \mathrm{CT}$ scans of the specimens fabricated at power levels of $240 \mathrm{~W}, 320 \mathrm{~W}$, and $380 \mathrm{~W}$ were analyzed by segmenting the images for pores containing at least five voxels, which, thereby, filtered out defects smaller than $12 \mu \mathrm{m}$ in size. Figure 5 shows the pore volume distribution as a function of the maximum Feret diameter of the pores in the $18 \mathrm{Ni}-300$ maraging steel processed at the $240 \mathrm{~W}, 320 \mathrm{~W}$, and $380 \mathrm{~W}$ power levels. It is noteworthy that the maximum Feret diameter of each pore is the length of its longest axis; thus, the Feret diameter will usually vary much more for irregularly shaped pores relative to regularly shaped (spherical) pores. Considering this, a key observation from Figure 5 is the similar pore characteristics for the $240 \mathrm{~W}$ and $320 \mathrm{~W}$ conditions. Nonetheless, LPBF processing at $320 \mathrm{~W}$ seems to result in a greater volume of smaller pores $(15 \mu \mathrm{m}$ to $30 \mu \mathrm{m})$ and a lower volume of coarser pores $(35 \mu \mathrm{m}$ to $50 \mu \mathrm{m}$ ) relative to the $240 \mathrm{~W}$ condition, which may point to a slightly more improved situation for densification at $320 \mathrm{~W}$ relative to the $240 \mathrm{~W}$ power level. Further increases in the power level to $380 \mathrm{~W}$, however, led to an increase in the volume of coarser pores (i.e., $60 \mu \mathrm{m}$ to $>100 \mu \mathrm{m}$ ). The formation of coarser pores at $380 \mathrm{~W}$ can be attributed to excessive power level, which promotes evaporation, the 
development of gas bubbles, and the eventual coalescence of many small pores into fewer larger pores [49].
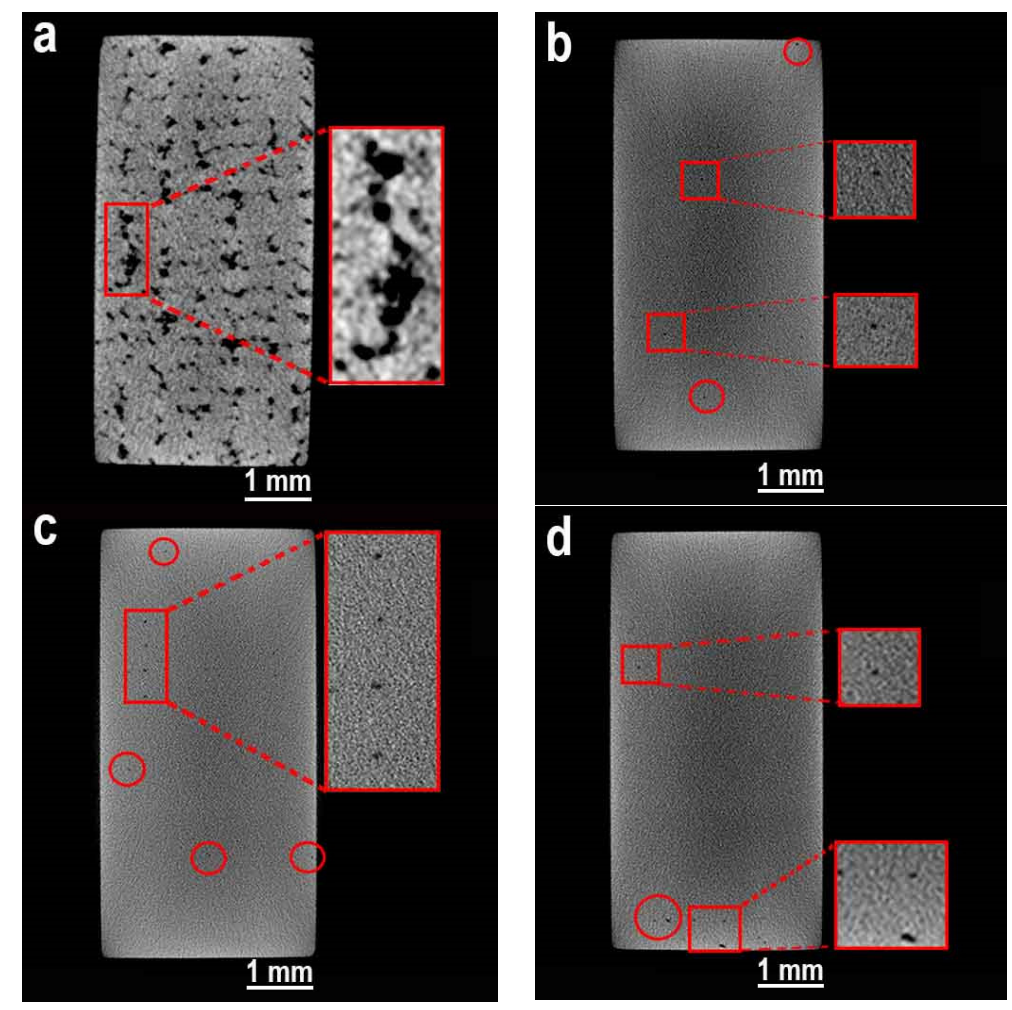

Figure 4. Representative TD images from X-ray $\mu \mathrm{CT}$ scanning of the gage length in the tensile specimens extracted from the coupons fabricated at: (a) $160 \mathrm{~W}$, (b) $240 \mathrm{~W}$, (c) $320 \mathrm{~W}$, and (d) $380 \mathrm{~W}$ power levels.

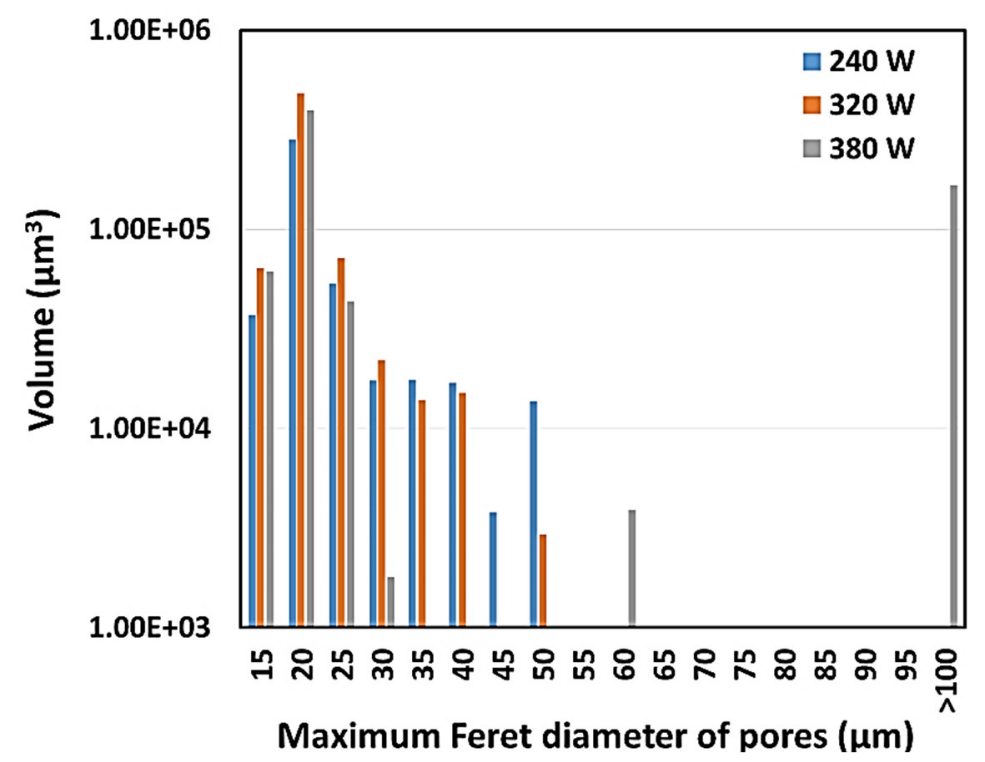

Figure 5. Plot of the pore volume versus their maximum Feret diameter determined from $\mu \mathrm{CT}$ analyzes of the specimens produced at $240 \mathrm{~W}, 320 \mathrm{~W}$, and $380 \mathrm{~W}$.

The density values measured by the Archimedes and He gas pycnometry methods are tabulated in Table 4 for $18 \mathrm{Ni}-300$ maraging steel manufactured at the different power levels. The $160 \mathrm{~W}$ power level produced the lowest densities of $7.56 \mathrm{~g} / \mathrm{cm}^{3}$ and $7.98 \mathrm{~g} / \mathrm{cm}^{3}$, as measured by the Archimedes and gas pycnometry methods, respectively. The low relative 
densities (93.3-98.5\%), which signify the highest amount of pores measured for the $160 \mathrm{~W}$ condition, agree well with the X-ray $\mu \mathrm{CT}$ observations in Figure $4 \mathrm{a}$ of large interconnected pores with lack of fusion layers that were attributed to the low infill ED $\left(38.1 \mathrm{~J} / \mathrm{mm}^{3}\right)$. By contrast, the other three power levels showed significantly higher densities with relative densities ranging from $99.0 \%$ to $99.8 \%$. However, considering the standard deviation values of the density datasets, the densities measured by the Archimedes and gas pycnometry methods for $240 \mathrm{~W}, 320 \mathrm{~W}$, and $360 \mathrm{~W}$ are statistically equivalent. Nonetheless, the $320 \mathrm{~W}$ condition-with the highest Archimedes density of $8.07 \mathrm{~g} / \mathrm{cm}^{3}$ —possibly ranks slightly better than the $240 \mathrm{~W}$ and $380 \mathrm{~W}$ power levels, especially when including the $\mu \mathrm{CT}$ observations (Figure 4) and analyzes (Figure 5).

Table 4. Density and porosity characteristics of $18 \mathrm{Ni}-300$ maraging steel produced by hybrid (LPBF) manufacturing.

\begin{tabular}{|c|c|c|c|c|c|c|}
\hline $\begin{array}{c}\text { Power } \\
\text { Level (W) }\end{array}$ & $\begin{array}{l}\text { Infill ED } \\
\left(\mathrm{J} / \mathrm{mm}^{3}\right)\end{array}$ & $\begin{array}{c}\text { Density } \\
\text { Archimedes } \\
\left(\mathrm{g} / \mathrm{cm}^{3}\right)\end{array}$ & STD & $\begin{array}{c}\text { Density } \\
\text { Pycnometer } \\
\left(\mathrm{g} / \mathrm{cm}^{3}\right)\end{array}$ & STD & $\begin{array}{c}\text { Closed } \\
\text { Porosity from } \\
\mu C T *(\%)\end{array}$ \\
\hline 160 & 38.1 & 7.56 & 0.01 & 7.98 & 0.04 & $\mathrm{~N} / \mathrm{A}$ \\
\hline 240 & 57.1 & 8.02 & 0.02 & 8.08 & 0.05 & 0.002 \\
\hline 320 & 76.2 & 8.07 & 0.08 & 8.08 & 0.06 & 0.003 \\
\hline 380 & 90.5 & 8.04 & 0.02 & 8.08 & 0.05 & 0.003 \\
\hline
\end{tabular}

* Segmentation of images in analysis excluded sizes smaller than $12 \mu \mathrm{m}$, so the closed porosity measured by $\mu \mathrm{CT}$ is underestimated relative to the bulk density by Archimedes and pycnometry.

\subsection{Macro/Microstructures}

Representative 2D macrostructures, imaged optically on the three orthogonal planes, are shown in Figure $6 \mathrm{a}-\mathrm{d}$ for the $18 \mathrm{Ni}-300$ maraging steel produced at the four power levels. For the $160 \mathrm{~W}$ condition, the microstructure on all three orthogonal planes (Figure 6a) showed numerous large, irregularly shaped, and interconnected pores (i.e., black regions in optical images). The microstructures along the BD-X-Z and Y-Z planes-showed that these pores were preferentially located in the interlayers that exhibited lack of fusion characteristics and the occasional balling behavior due to insufficient melting of the powder layers at the low applied power level $(160 \mathrm{~W})$ and infill ED $\left(38.1 \mathrm{~J} / \mathrm{mm}^{3}\right)$. Such defects have also been observed previously during LPBF processing of other metals, such as titanium and aluminum alloys [50,51], when the insufficient energy input caused an increase in the melt pool discontinuity and created layered lack of fusion defects, which manifested as irregularly-shaped pores with un-melted metal powders.

The macrostructures of the $18 \mathrm{Ni}-300$ maraging steel manufactured at the higher power levels of $240 \mathrm{~W}$ (Figure 6b), $320 \mathrm{~W}$ (Figure 6c) and $380 \mathrm{~W}$ (Figure 6d) were also examined optically in the three orthogonal planes, comprising the $X-Y$ plane in the transverse direction (TD) which is normal to $X-Z$ and $Y-Z$ planes in the BD. In both the TD and BD, the improved densification characteristics were apparent for all three power levels, as the macrostructures showed no cracking (that is often difficult to detect through $\mu \mathrm{CT}$ ) and only a limited number of small pores. This finding corroborates well with the high relative densities $(>99.0 \%)$, as well as the pore size and distribution results in Figure 5.

Furthermore, for the $240 \mathrm{~W}$ condition (infill ED of $57.1 \mathrm{~J} / \mathrm{mm}^{3}$ ), the rastering scan pattern and the layer-by-layer rotation (at an angle of $90^{\circ}$ ) applied during LPBF processing of 18Ni-300 maraging steel was clearly evident in the TD, as displayed in Figure $6 \mathrm{~b}$. The average width of the scan tracks for the $240 \mathrm{~W}$ condition was roughly $122 \mu \mathrm{m}$, approximately equal to the $\mathrm{h}=120 \mu \mathrm{m}$ selected/used in the present study. Increasing the power level to $320 \mathrm{~W}$ (infill ED of $76.2 \mathrm{~J} / \mathrm{mm}^{3}$ ) or $380 \mathrm{~W}$ (infill ED of $90.5 \mathrm{~J} / \mathrm{mm}^{3}$ ) had the effect of smoothing the scan tracks and rendering the rastering pattern less distinctly visible, as seen by comparing Figure $6 \mathrm{c}, \mathrm{d}$, respectively, and with Figure $6 \mathrm{~b}$ for the $240 \mathrm{~W}$ condition. With increasing power level, the average width of the scan tracks was also observed to increase $(134 \mu \mathrm{m}$ at $320 \mathrm{~W}$ and $153 \mu \mathrm{m}$ at $380 \mathrm{~W})$. By contrast, along the BD, the macrostructure consisted of overlapping melt pool boundaries with an average melt pool (bead) width 
and depth of $138 \mu \mathrm{m}$ and $105 \mu \mathrm{m}$, respectively, for the $240 \mathrm{~W}$ condition. As the melt pool dimensions also depend on the processing parameters (laser spot size/diameter, ED, layer thickness, etc.) [52], with increasing power level during LPBF processing, the bead width increased from $138 \mu \mathrm{m}$ at $240 \mathrm{~W}$, to $154 \mu \mathrm{m}$ at $320 \mathrm{~W}$, and $173 \mu \mathrm{m}$ at $380 \mathrm{~W}$. This is in agreement with reported studies on LPBF processing of steels that showed increasing bead width with increasing power level [53,54].
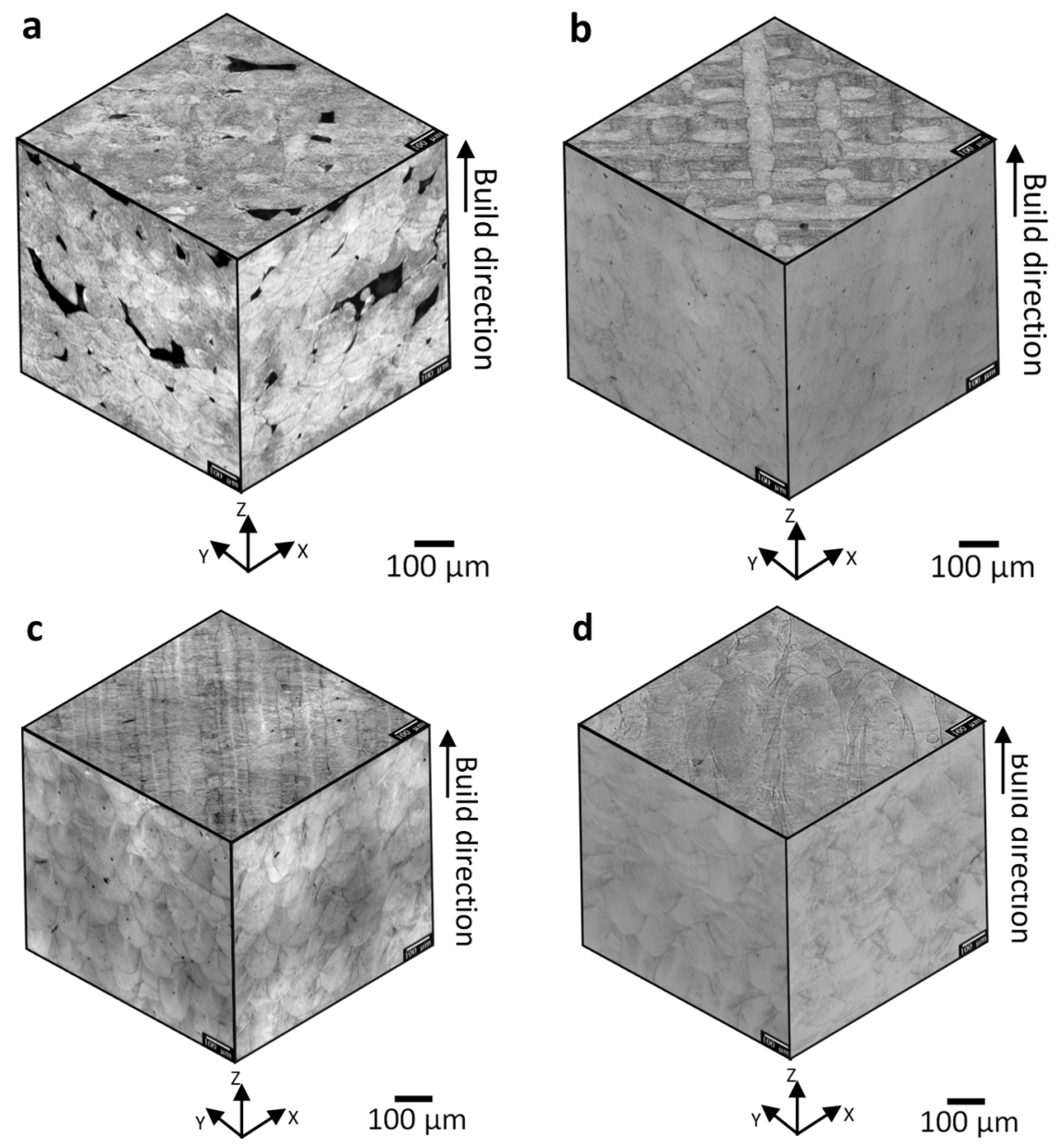

Figure 6. Representative optical microscopy images on the three orthogonal planes of the as-printed maraging steel at different powers (a) $160 \mathrm{~W}$, (b) $240 \mathrm{~W}$, (c) $320 \mathrm{~W}$, and (d) $380 \mathrm{~W}$.

Closer examination of the individual melt pools within the as-printed macrostructure of the $18 \mathrm{Ni}-300$ maraging steel revealed a microstructure consisting of remnant solidification cells, as shown in Figure 7a,b for the BD and TD. Within the epitaxially grown grains, the different remnant cells were observed to have an average spacing of $\sim 0.67 \mu \mathrm{m}$ with orientations mostly perpendicular to the melt pool boundaries, but other directions were also observed, owing to the preferential growth direction (100) in cubic structures, as discussed theoretically in [55]. The presence of such remnant cellular structures within the melt pool boundaries of $18 \mathrm{Ni}-300$ maraging steels is inherent to the rapid rate of melt pool solidification (on the order of $10^{6}{ }^{\circ} \mathrm{C} / \mathrm{s}$ ) during LPBF processing [56-58]. 

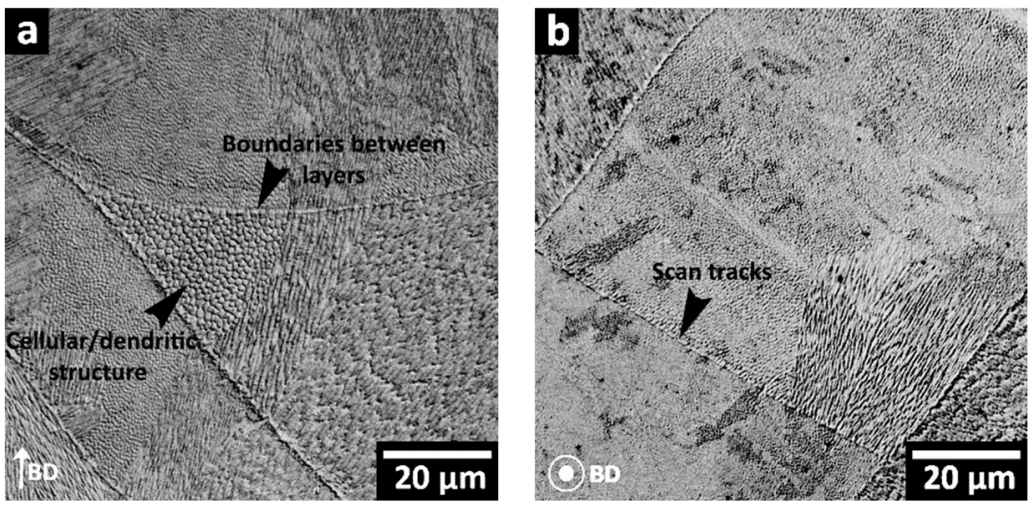

Figure 7. Representative optical microscopy images of as-printed maraging steel (a) along the BD and (b) normal to the BD (TD).

\subsection{Mechanical Properties}

The mechanical properties of the $18 \mathrm{Ni}-300$ maraging steel manufactured at the different power levels were first measured through hardness testing; the average bulk hardness was determined by Rockwell testing on a C scale, while the microhardness was measured by the Vickers test. The average hardness values of the $18 \mathrm{Ni}-300$ maraging steels produced at the four different power levels are tabulated in Table 5. At the lowest power level of $160 \mathrm{~W}$, the average hardness was $25.3 \pm 4.7 \mathrm{HRC}$ and $353.8 \pm 25.2 \mathrm{HV}_{0.5}$. Additionally, the microhardness values in the $\mathrm{BD}$ and TD of $359.2 \pm 13.3 \mathrm{HV}_{0.5}$ and $348.4 \pm 37.1 \mathrm{HV}_{0.5}$, respectively, showed considerable scattering of the data, as evident from the high standard deviations calculated. Compared to the $160 \mathrm{~W}$ condition, increasing the power level to $240 \mathrm{~W}, 320 \mathrm{~W}$, and $380 \mathrm{~W}$ increased the hardness considerably-by more than $40 \%$ in Rockwell C hardness and $\sim 6 \%$ in Vickers microhardness. Moreover, with increasing power from $240 \mathrm{~W}$ to $380 \mathrm{~W}$, there appeared to be the possible trend of increasing hardness; however, considering the standard deviations, the measured bulk hardness values (ranging from 35.9 to $37.2 \mathrm{HRC}$ ), as well as the Vickers microhardness values in the TD (ranging from 379.7 to $383.8 \mathrm{HV}_{0.5}$ ) and in the $\mathrm{BD}$ (ranging from 379.2 to $381.9 \mathrm{HV}_{0.5}$ ), are more likely to be statistically equivalent. This is clearly illustrated in Figure $8 \mathrm{a}, \mathrm{b}$ that shows the extent of scattering in the microhardness data in the TD and BD for the $18 \mathrm{Ni}-300$ maraging steel manufactured at the four power levels. In case of the $160 \mathrm{~W}$ condition, the high data scatter can be attributed to low microhardness regions measured in the vicinity of the lack of fusion layered defects or areas with large interconnected pores in the macrostructure (Figure 6a). The presence of these defects and the low relative density $(93.3 \%$ ) in the $160 \mathrm{~W}$ condition compromise both the microhardness and bulk hardness relative to that obtained for the $18 \mathrm{Ni}-300$ maraging steel manufactured at the higher power levels, which had no lack of fusion defects (isolated pores only), lower amounts of porosity, and relative densities above $99.0 \%$. Finally, as a point of comparison for these hardness values measured in the current study, the bulk hardness of conventionally manufactured (by hot rolling) $18 \mathrm{Ni}-300$ maraging steel in the annealed condition has been reported as 30-32 HRC [2]. The higher hardness of the $18 \mathrm{Ni}-300$ maraging steel manufactured additively has been attributed to the fine microstructure that results from the rapid cooling conditions during LPBF processing [26]. Previously, Bai et al. [11] reported an average microhardness value of $381 \mathrm{HV}_{0.2}$, and Chada et al. [59] reported $35 \pm 1 \mathrm{HRC}$ for as-printed $18 \mathrm{Ni}-300$ maraging steel manufactured with stand-alone LPBF technologies, which support the present findings for the $18 \mathrm{Ni}-300$ maraging steel produced by hybrid manufacturing with the Matsuura LUMEX Avance-25 technology reasonably well. 
Table 5. Average hardness values of maraging steel coupons manufactured by hybrid (LPBF) manufacturing at different power levels.

\begin{tabular}{|c|c|c|c|c|c|c|c|}
\hline $\begin{array}{l}\text { Power Level } \\
\text { (W) }\end{array}$ & $\begin{array}{c}\text { ED } \\
\left(\mathrm{J} / \mathrm{mm}^{3}\right)\end{array}$ & $\begin{array}{c}\text { Rockwell Hardness } \\
\text { (HRC) }\end{array}$ & STD & $\begin{array}{c}\text { Vickers } \\
\text { Microhardness } \\
\left(\mathrm{HV}_{0.5}\right) \text { in TD }\end{array}$ & STD & $\begin{array}{c}\text { Vickers } \\
\text { Microhardness } \\
\left(\mathrm{HV}_{0.5}\right) \text { in BD }\end{array}$ & STD \\
\hline 160 & 38.1 & 25.3 & 4.7 & 359.2 & 13.3 & 348.4 & 37.1 \\
\hline 240 & 57.1 & 35.9 & 1.3 & 379.7 & 3.9 & 381.9 & 7.1 \\
\hline 320 & 76.2 & 36.8 & 2.6 & 380.3 & 4.6 & 379.2 & 15.1 \\
\hline 380 & 90.5 & 37.2 & 1.2 & 383.8 & 4.1 & 381.3 & 23.7 \\
\hline
\end{tabular}

a

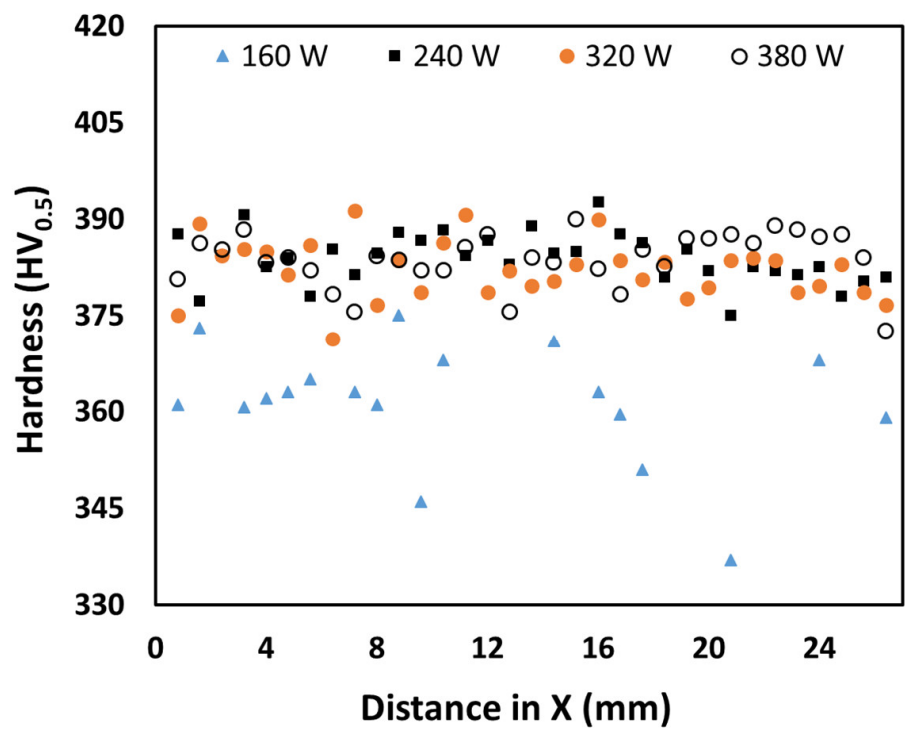

b

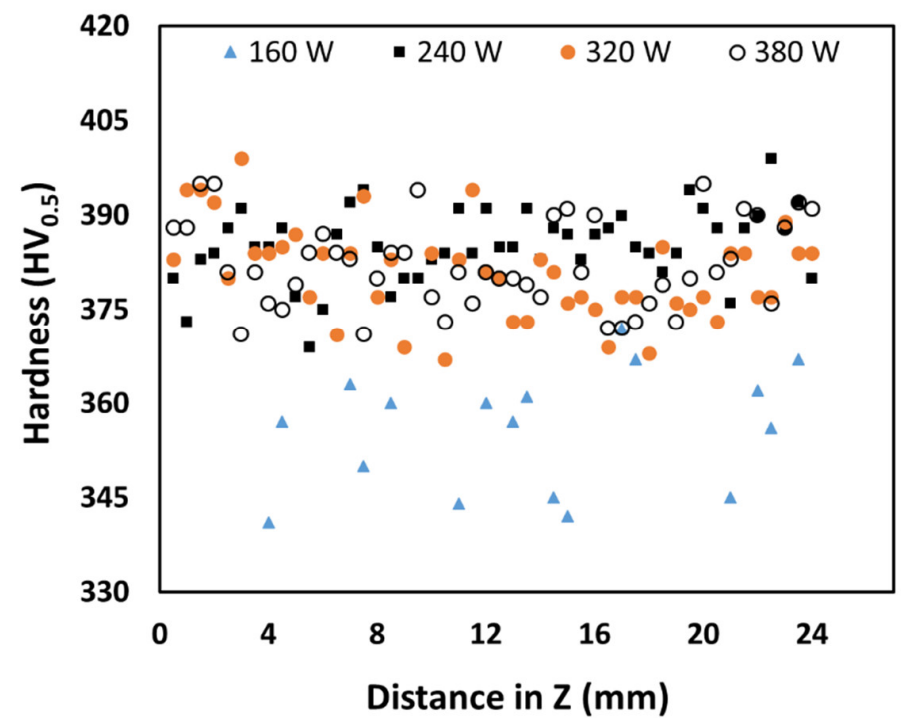

Figure 8. Variation in the microhardness of $18 \mathrm{Ni}-300$ maraging steel produced by hybrid (LPBF) manufacturing at different power levels: (a) TD and (b) BD.

Next, the mechanical response of the as-printed $18 \mathrm{Ni}-300$ maraging steel was evaluated by uniaxial tensile testing to obtain the engineering strain-stress curves, as shown in Figure 9, and to determine the average values for the YS, UTS, EL, and E, as tabulated in Table 6 for the coupons built at the four different power levels. For the $160 \mathrm{~W}$ condition, early failure of the specimens occurred at relatively low tensile stresses and strains relative 
to the other three power levels. This is unsurprising considering the low relative density $(93.3 \%)$ and the characteristics of defects observed — such as the large interconnected pores and the layered lack of fusion defects-in the X-ray $\mu \mathrm{CT}$ images (Figure $4 \mathrm{a}$ ) and the macrostructure (Figure $6 \mathrm{a}$ ) of the $18 \mathrm{Ni}-300$ maraging steel manufactured at $160 \mathrm{~W}$. Overall, for the $160 \mathrm{~W}$ power level, the tensile properties of the maraging steel were about $30 \%$ lower in strength (both YS and UTS), 24\% lower in stiffness (E) and more than $80 \%$ lower in ductility (EL) relative to $240 \mathrm{~W}$ condition. On the other hand, the tensile mechanical responses of the $18 \mathrm{Ni}-300$ maraging steel printed at $240 \mathrm{~W}, 320 \mathrm{~W}$, and $380 \mathrm{~W}$ were mostly similar, as shown in Figure 9, and the measured tensile properties indicated relatively high values for the YS (1005.6-1061.9 MPa), UTS (1157.6-1171.3 MPa), E (160.6-169.7 GPa), and EL (12.5-12.8\%), which corroborates well with previously discussed results of the pore characteristics from the $\mu \mathrm{CT}$, density, and macrostructure. Here, it is worth pointing out that the difference in relative density between the $160 \mathrm{~W}$ condition and the three other power levels was minor (at $\sim 6 \%$ ). Thus, the disparate characteristics of the pores-large, elongated, and interconnected for the $160 \mathrm{~W}$ condition versus fine, rounded, and isolated for the $240 \mathrm{~W}, 320 \mathrm{~W}$, and $380 \mathrm{~W}$ conditions-more likely had a greater impact on the mechanical performance. In this regard, it is interesting to note the slightly better strength properties of the $320 \mathrm{~W}$ condition that had a larger amount of finer pores and a smaller amount of larger pores (Figure 5) relative to the $240 \mathrm{~W}$ condition. Furthermore, coarsening of the pores in the $380 \mathrm{~W}$ condition was seen to reduce the tensile properties by about $4 \%$ in the $\mathrm{YS}, 3 \%$ in the EL and $5 \%$ in the E.

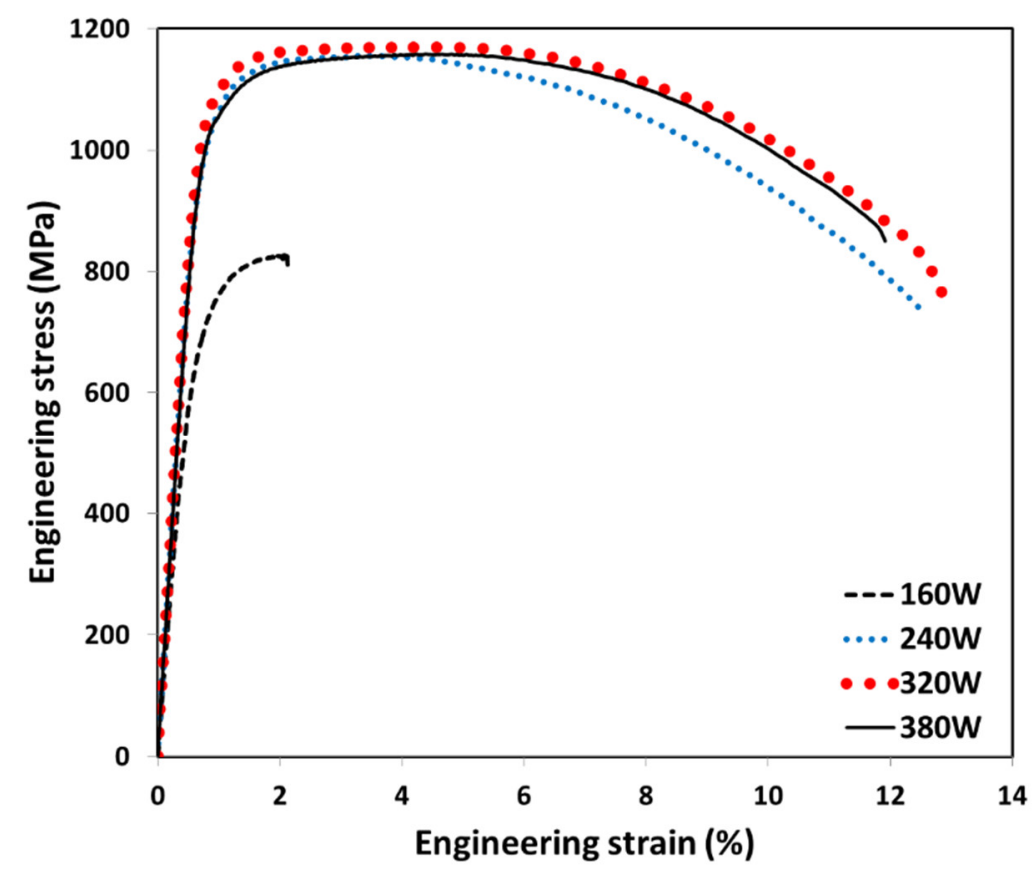

Figure 9. Average tensile stress-strain curves for $18 \mathrm{Ni}-300$ maraging steel produced by hybrid (LPBF) manufacturing at power levels of $160 \mathrm{~W}, 240 \mathrm{~W}, 320 \mathrm{~W}$, and $380 \mathrm{~W}$.

Table 6. Average as-printed tensile properties of $18 \mathrm{Ni}-300$ maraging steel produced by hybrid (LPBF) manufacturing at different power levels.

\begin{tabular}{cccccccccc}
\hline $\begin{array}{c}\text { Power } \\
(\mathbf{W})\end{array}$ & $\begin{array}{c}\text { ED } \\
\left(\mathbf{J} / \mathbf{m m}^{\mathbf{3}} \mathbf{)}\right.\end{array}$ & $\begin{array}{c}\text { UTS } \\
\mathbf{( M P a})\end{array}$ & STD & $\begin{array}{c}\text { YS } \\
\mathbf{( M P a )}\end{array}$ & STD & $\begin{array}{c}\text { EL } \\
\mathbf{( \% )}\end{array}$ & STD & $\begin{array}{c}\text { E } \\
(\mathbf{G P a})\end{array}$ & STD \\
\hline 160 & 38.1 & 827.0 & 2.0 & 695.2 & 26.3 & 2.1 & 0.1 & 128.9 & 5.8 \\
240 & 57.1 & 1157.6 & 2.6 & 1005.6 & 14.7 & 12.8 & 0.7 & 169.2 & 4.7 \\
320 & 76.2 & 1171.3 & 5.4 & 1061.9 & 13.7 & 12.9 & 0.4 & 169.7 & 3.4 \\
380 & 90.5 & 1159.6 & 10.7 & 1022.4 & 19.3 & 12.5 & 0.8 & 160.6 & 1.4 \\
\hline
\end{tabular}


A further reflection is for the engineering stress-strain curves of the $240 \mathrm{~W}, 320 \mathrm{~W}$, and $380 \mathrm{~W}$ conditions (as given in Figure 9) that show a combination of high UTS and moderate ductility (total strain of $\sim 12 \%$ ), indicating relatively high energy absorption before failure. More specifically, these three curves show a similar mechanical response within the initial 4-5\% strain region under elastic-to-homogeneous plastic loading conditions, that is, just before reaching the peak stress. After the peak stress, a considerable amount of further straining occurs, representing more than $60 \%$ of the total EL to fracture, as observed in Figure 9 . This behavior-with a peak stress at small plastic strains followed by a prolonged region of continued decrease in stress-observed for the $18 \mathrm{Ni}-300$ maraging steel has been reported in other studies $[60,61]$.

The tensile properties obtained in the present study for the $320 \mathrm{~W}$ condition are compared in Table 7 with reported data in the open literature from research studies using stand-alone 3D printers for AM of $18 \mathrm{Ni}-300$ maraging steel [21,44,62-65], as well as for the wrought equivalent alloy [1]. The tensile properties of $18 \mathrm{Ni}-300$ maraging steel manufactured using a hybrid (LPBF) manufacturing process using the Matsuura LUMEX Avance-25 in the present work shows comparable values and, in some cases, superior tensile properties than that obtained from conventional stand-alone LPBF technologies. The differences can be attributed to the powder composition, process parameters, scanning strategy, heat input, additive system, etc. Moreover, the tensile properties of 18Ni-300 maraging steel produced using hybrid (LPBF) manufacturing or stand-alone LPBF technologies fall in the range of performance data for wrought equivalent alloy in the annealed condition [1], except for the usual lower E values and, in some cases, also the YS [26,66]; this latter may be related to lower strain hardenability effects as discussed in [59,61].

Table 7. Comparison of the as-built tensile properties of $18 \mathrm{Ni}-300$ maraging steels produced by hybrid (LPBF) manufacturing using the Matsuura Lumex Avance-25 with conventional (stand-alone) AM or conventional wrought manufacturing.

\begin{tabular}{|c|c|c|c|c|}
\hline AM Systems & YS (MPa) & UTS (MPa) & EL (\%) & E (GPa) \\
\hline $\begin{array}{l}\text { Matsuura LUMEX Avance-25 } \\
\text { (Current study) }\end{array}$ & 1062 & 1171 & 12.9 & 169.7 \\
\hline Matsuura LUMEX Avance-25 [26] & $\sim 300$ * & 1125 & 10.4 & 163.0 \\
\hline Matsuura LUMEX Avance-25 [24] & 1111 & 1205 & 14.0 & 154.0 \\
\hline EOSINT M280 [66] & 555 & 1173 & 10.9 & 128.9 \\
\hline EOSINT M280 [65] & 1069 & 1174 & 15.7 & 161.0 \\
\hline EOSINT M290 [55] & 915 & 1165 & 12.4 & NA \\
\hline EOSINT M290 [59] & 1155 & 1215 & 15 & NA \\
\hline EOSINT M290 [67] & 903 & 1050 & 8 & NA \\
\hline EOS as-built [44] & 1050 & 1100 & 10.0 & 160.0 \\
\hline Concept Laser M2 Laser Cusing [62] & 1050 & 1100 & 12.1 & 194.0 \\
\hline Concept Laser M2 Laser Cusing [21] & 768 & 1260 & 13.9 & $\mathrm{~N} / \mathrm{A}$ \\
\hline Concept Laser M3 [68] & 1214 & 1290 & 13.3 & 163.0 \\
\hline Renishaw AM250 [63] & 915 & 1188 & 6.1 & NA \\
\hline SLM solution 280HL [69] & 999 & 1080 & 11.3 & NA \\
\hline $\begin{array}{l}\text { Wrought 18Ni-300 Maraging Steel } \\
\text { in Annealed Condition [1] }\end{array}$ & $760-895$ & 1000-1170 & $6-15$ & 180 \\
\hline
\end{tabular}

* From stress-strain curve.

\section{Fractography}

After static tensile testing, the fracture surfaces of select specimens at each power level were examined using SEM, as shown in Figure 10. For the $160 \mathrm{~W}$ condition, the fractured surface showed un-melted powder particles, within the large interconnected pores that were irregular in size (Figure 10a,b), as well as the lack of fusion regions between the layers (Figure 10b), which reasonably explains the early failure of the tensile specimens during mechanical property testing and the resulting low strength, ductility, and stiffness. By contrast, the fractographs of the $240 \mathrm{~W}$ (Figure 10c,d), $320 \mathrm{~W}$ (Figure 10e,f), and $380 \mathrm{~W}$ (Figure 10g,h) specimen conditions showed fractures exhibiting small rounded pores, which 
were remnant in the microstructure after LPBF processing, and the distinct formation of dimples on the fracture surfaces. These dimples are characteristic of a ductile failure mechanism that progresses through micro-void formation, growth, and coalescence, which eventually leads to micro-cracking and transgranular tearing through the material. Overall, no significant differences in the fracture surface features were observed between the $240 \mathrm{~W}$ and $320 \mathrm{~W}$ conditions, but the pores were slightly larger on the tensile surfaces of the $380 \mathrm{~W}$ condition.
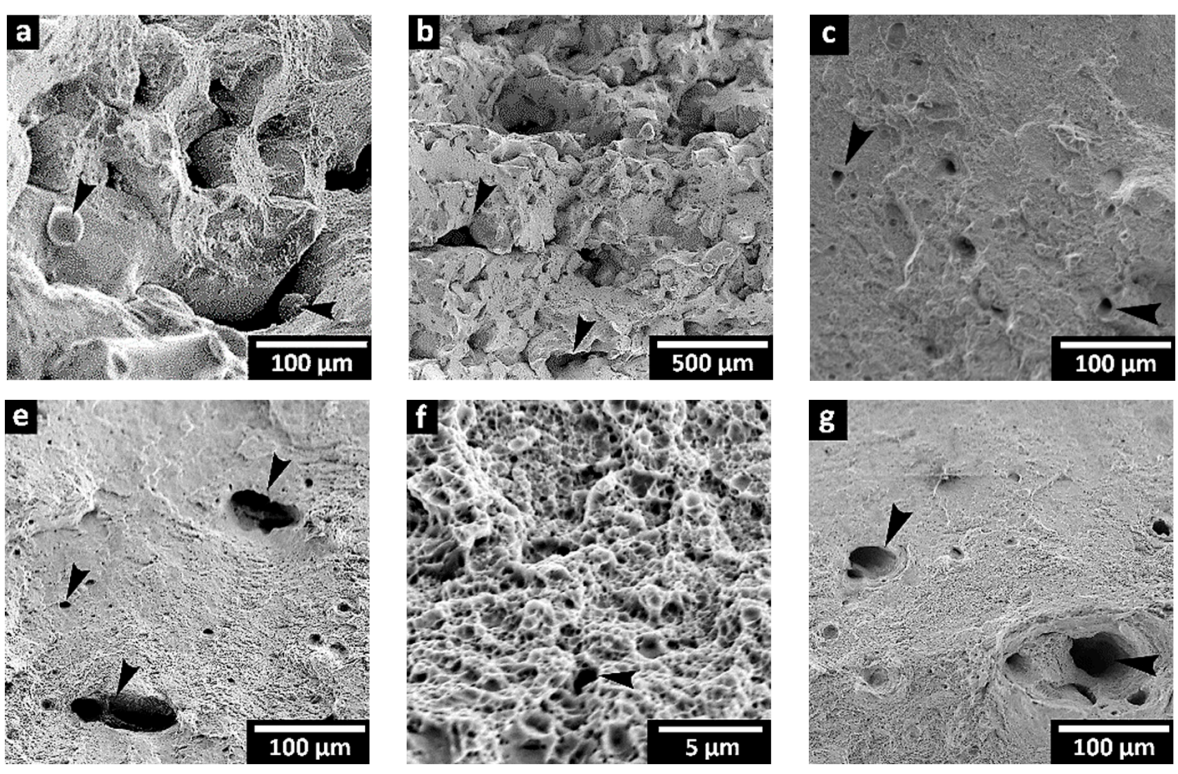

Figure 10. SEM fractographs showing the fracture surfaces after tensile loading in the TD of $18 \mathrm{Ni}-300$ maraging steel produced by hybrid (LPBF) manufacturing at different powers: (a,b) $160 \mathrm{~W},(\mathbf{c}, \mathbf{d}) 240 \mathrm{~W},(\mathbf{e}, \mathbf{f}) 320 \mathrm{~W}$, and (g,h) $380 \mathrm{~W}$.

\section{Discussion and Future Scope}

The knowledge gained from this present study, on the effect of the power level in the LPBF process on the geometry, surface finish, porosity characteristics, mechanical properties, and fracture behavior, is important for advancing hybrid manufacturing capability for the production of high-quality maraging steel parts with the required performance. Due to the newness of the hybrid (LPBF) manufacturing technology, very limited research has been undertaken to date relative to studies on stand-alone LPBF processing of $18 \mathrm{Ni}-300 \mathrm{marag}-$ ing steel, as evidenced by the reported data in Table 7. Amongst the reported data on hybrid (LPBF) manufacturing of 18Ni-300 maraging steel, the early research work of Enemuoh et al. [24] examined the density and mechanical properties of test specimens printed using the Matsuura LUMEX Avance-25 system; however, the process parameters were not disclosed and, without characterization of the powder, porosity and macro/microstructures, linkages to interrelate the materials, and process parameters to the performance was not possible. Around this same time, Mutua et al. [26] explored the processing window for hybrid (LPBF) manufacturing of $18 \mathrm{Ni}-300$ maraging steel through a design of experiment approach to broadly vary the power level (100-400 W), scan speed (400-1000 mm/s), pitch $(0.025-0.2 \mathrm{~mm})$, and spot diameter $(0.05-0.3 \mathrm{~mm})$; through their findings, an optimum process window was proposed and, for a scan speed of $700 \mathrm{~mm} / \mathrm{s}$, the lower and upper boundaries for the power level were projected to be $160 \mathrm{~W}$ and $320 \mathrm{~W}$, respectively, based on a single validation point. In keeping with these findings of Mutua et al. [26], the current research was deliberated to more closely examine the optimal process window for hybrid (LPBF) manufacturing of $18 \mathrm{Ni}-300$ maraging steel through a systematic variation of the power level from $160 \mathrm{~W}$ to $380 \mathrm{~W}$, with the infill scan speed, pitch, and spot diameter held constant at $700 \mathrm{~mm} / \mathrm{s}, 0.12 \mathrm{~mm}$, and $0.2 \mathrm{~mm}$, respectively, so as to match the previously reported validation parameters [26]. Through the current study, for the first time, the manufacturer's reference powder for $18 \mathrm{Ni}-300$ maraging steel was characterized and its 
densification evolution was understood through detailed $\mu \mathrm{CT}$ analysis of the pores. These findings clearly indicated that the characteristics of the $160 \mathrm{~W}$ condition (with large lack of fusion defect layers and irregularly-shaped interconnected pores) are far from optimal, as validated through surface finish characteristics, macro/microstructural analysis, hardness and tensile properties, as well as fractography. In addition, the $380 \mathrm{~W}$ condition, though considerably better than the $160 \mathrm{~W}$ condition, represents an upper limit for the power level, as coarsening of the pores was observed and linked to slightly lower tensile properties. With an eye on the statistical significance of the properties measured, the $240 \mathrm{~W}$ and $320 \mathrm{~W}$ power levels for hybrid (LPBF) manufacturing of $18 \mathrm{Ni}-300$ maraging steel are equivalent, though the pore size distribution of the latter condition may prove to be more efficacious under future cyclic loading. Thus, the results from the present study delimit a more robust optimum (Table 8 ) for the processing window using a power level between $240 \mathrm{~W}$ (infill $\mathrm{ED}=57.1 \mathrm{~J} / \mathrm{mm}^{3}$ ) and $380 \mathrm{~W}$ (infill $\mathrm{ED}=90.5 \mathrm{~J} / \mathrm{mm}^{3}$ ) during hybrid (LPBF) manufacturing of $18 \mathrm{Ni}-300$ maraging steel; this new optimal process window is also shifted slightly to higher power levels with respect to the process map proposed by Mutua et al. [26]. The comprehensive analysis presented in the current study also shows the close relationship between porosity evolution and power level during hybrid (LPBF) processing of $18 \mathrm{Ni}-300$ maraging powder, specifically in relation to the understanding of their impact on the material allowable (property) data, which is important for engineering advanced designs and products for diverse applications in industry. Furthermore, having established this robust process window in the present study, future investigation of the fatigue and/or thermomechanical fatigue properties of the maraging steel produced by hybrid (LPBF) manufacturing can be deliberated and analyzed under conditions representative of realistic thermal and mechanical service loads. Of equal importance for future work is the evaluation of the impact of hybrid (LPBF) parameters on the residual stresses and the concomitant development of a 2D finite element model that couples the influence of machining parameters with LBPF processing to predict residual stresses, distortion, and properties. It is expected that this additional experimental and simulation knowhow will further assist process engineers to rapidly design and scale the conditions within the parametric window for hybrid manufacturing of complex geometry parts.

Table 8. Optimal/robust window for LPBF process parameters during hybrid manufacturing of the 18Ni-300 maraging steel.

\begin{tabular}{ccccccc}
\hline Parameters & $\mathbf{h}(\boldsymbol{\mu m})$ & $\mathbf{t}(\boldsymbol{\mu m})$ & $\mathbf{d}(\boldsymbol{\mu m})$ & $\mathbf{v}(\mathbf{m m} / \mathbf{s})$ & $\mathbf{P}(\mathbf{W})$ & ED $(\mathbf{J} / \mathbf{m m} 3)$ \\
\hline Infill & 120 & 50 & 200 & 700 & $240-380$ & $57.1-90.5$ \\
\hline Contour & 120 & 50 & 200 & 1400 & $240-380$ & $28.6-45.2$ \\
\hline
\end{tabular}

\section{Conclusions}

The aim of the presented study was to understand the effect of power level on the porosity evolution and material performance of $18 \mathrm{Ni}-300$ maraging steel produced by in-envelope hybrid manufacturing that combines laser powder bed fusion (LPBF) additive manufacturing with machining. From this research, the following conclusions can be drawn:

1. Inspection of the part dimensions after hybrid (LPBF) manufacturing indicated high accuracy in the final geometry with the overall deviations (with respect to the CAD model) ranging from about $30 \mu \mathrm{m}$ to $160 \mu \mathrm{m}$ for the as-printed surfaces and $10 \mu \mathrm{m}$ and $110 \mu \mathrm{m}$ for machined surfaces.

2. The linear and areal surface roughness parameters on the as-printed vertical side-wall surfaces were lowest for the $240 \mathrm{~W}\left(57.1 \mathrm{~J} / \mathrm{mm}^{3}\right)$ condition compared to the $160 \mathrm{~W}$ $\left(38.1 \mathrm{~J} / \mathrm{mm}^{3}\right), 320 \mathrm{~W}\left(76.2 \mathrm{~J} / \mathrm{mm}^{3}\right)$, and $380 \mathrm{~W}\left(90.5 \mathrm{~J} / \mathrm{mm}^{3}\right)$ power levels. Overall, for the as-printed surfaces at the four power levels, the measured Ra and Sa ranged from 9.54-12.26 $\mu \mathrm{m}$ and from 8.02-14.64 $\mu \mathrm{m}$, respectively. By contrast, the Ra and Sa for 
the machined surfaces were typically more than an order of magnitude lower than the as-printed surfaces.

3. Analysis of the pore characteristics (morphology, size, and distribution) and density were investigated by $\mathrm{X}$-ray $\mu \mathrm{CT}$, Archimedes, and helium gas pycnometry methods. The analysis showed that the $160 \mathrm{~W}$ condition produced the lowest relative densities $(93.3-98.5 \%)$ due to the presence of lack of fusion layers with unmelted powder and the large interconnected pores with irregular morphologies. Hybrid (LPBF) manufacturing at $240 \mathrm{~W}$ and $320 \mathrm{~W}$ showed improved densification, with the latter showing a greater volume of smaller pores $(15 \mu \mathrm{m}$ to $30 \mu \mathrm{m})$ and a lower volume of coarser pores $(35 \mu \mathrm{m}$ to $50 \mu \mathrm{m}$ ) relative to the former. Further increases in the power level to $380 \mathrm{~W}$ increased the volume of coarser pores $(60 \mu \mathrm{m}$ to $>100 \mu \mathrm{m})$, likely due to excessive energy input that promotes evaporation, the development of gas bubbles, and the eventual coalescence of many small pores into fewer larger pores. The relative densities measured for the $240 \mathrm{~W}, 320 \mathrm{~W}$, and $380 \mathrm{~W}$ were statistically equivalent and ranged from $99.0 \%$ to $99.8 \%$.

4. The coupons manufactured at $160 \mathrm{~W}$ showed the lowest hardness $(25.3 \pm 4.7 \mathrm{HRC}$ and $\left.353.8 \pm 25.2 \mathrm{HV}_{0.5}\right)$ and the tensile properties were $\sim 30 \%$ lower in strength, ductility, and stiffness (compared to the other three power levels), due to the low relative density (93.3\%). The higher densities attained at $240 \mathrm{~W}, 320 \mathrm{~W}$, and $380 \mathrm{~W}$ led to a considerably better mechanical performance that was determined to be statistically similar for the three power levels. Overall, the hardness ranged from 35.9-37.2 HRC and 379.2-383.8 $\mathrm{HV}_{0.5}$, the yield strength from 1005.6-1061.9 MPa, ultimate tensile strength from 1157.6-1171.3 MPa, elastic modulus from 160.6-169.7 GPa, and percent elongation from $12.5-12.8 \%$.

5. The current research on as-printed $18 \mathrm{Ni}-300$ maraging steel manufactured using a Matsuura LUMEX Avance-25 hybrid additive-subtractive technology has established comprehensive linkages between the power level, geometry, surface finish, and porosity evolution in the microstructure and mechanical properties, which has led to the definition of a robust optimal window for processing.

Author Contributions: Conceptualization, S.S., J.S., M.B., P.W. and J.G.; methodology, J.S., S.S., P.W., F.B., M.M.-Z. and J.G.; software, S.S., F.B. and J.S.; validation, M.M.-Z., P.W., M.B. and J.G.; formal analysis, S.S., F.S., M.O., F.B. and P.W.; investigation, S.S., F.B., F.S. and M.O.; resources, M.M.-Z., J.S., M.B. and J.G.; data curation, S.S., F.B., M.O. and F.S.; writing-original draft preparation, S.S. and P.W.; writing-review and editing, J.G., M.B., M.M.-Z., F.B., S.S., P.W., F.S., M.O. and J.S.; visualization, S.S., M.B. and P.W.; supervision, M.B., P.W., F.B. and J.G.; project administration, M.M.-Z., M.B., P.W., J.S. and F.B.; funding acquisition, M.M.-Z., M.B., P.W., J.G. and J.S. All authors have read and agreed to the published version of the manuscript.

Funding: This research received financial support from the Natural Sciences and Engineering Research Council of Canada (NSERC) under grant CRDPJ538319-1; Centre Quebecois de recherche et de developpement de l'aluminium (CQRDA) under grant CONT1058; National Research Council Canada (NRC) through the Aerospace Research Center and METALTec industrial R\&D group Advanced Manufacturing Program under A1-014126.

Institutional Review Board Statement: Not applicable.

Informed Consent Statement: Not applicable.

Data Availability Statement: The authors confirm that the data supporting the findings of this study are available within the article.

Acknowledgments: The authors wish to thank X. Pelletier, M. Guerin, and P. Dorber Squire of the National Research Council Canada for their technical assistance related inspection, metallographic preparation and mechanical testing.

Conflicts of Interest: The authors declare no conflict of interest. 


$\begin{array}{llll}\text { Abbreviations } & & \\ \text { 2D } & \text { Two dimensional } & \text { He } & \text { Helium } \\ \text { 3D } & \text { Three dimensional } & \text { HRC } & \text { Hardness Rockwell C-scale } \\ \text { AD } & \text { Apparent density } & \mathrm{HV}_{0.5} & \text { Vickers hardness at 500 g load } \\ \text { AM } & \text { Additive manufacturing } & \text { LPBF } & \text { Laser powder bed fusion } \\ \text { AOR } & \text { Angle of repose } & \mu & \text { micro } \\ \text { BD } & \text { Build direction } & \mathrm{P} & \text { Power } \\ \text { CAD } & \text { Computer-aided design } & \text { v } & \text { Scanning speed } \\ \text { CT } & \text { Computed tomography } & \text { SEM } & \text { Scanning electron microscope } \\ \text { d } & \text { Spot diameter } & \text { STD } & \text { Standard deviation } \\ \text { E } & \text { Elastic modulus } & \mathrm{t} & \text { Layer thickness } \\ \text { ED } & \text { Energy density } & \text { TD } & \text { Transverse direction } \\ \text { EDM } & \text { Electro-discharge machining } & \text { UTS } & \text { Ultimate tensile strength } \\ \text { EL } & \text { Elongation } & \text { YS } & \text { Yield strength } \\ \text { h } & \text { Hatch distance } & & \end{array}$

\section{References}

1. ASM International Handbook Committee. ASM Handbook, Properties and Selection: Irons, Steels, and High Performance Alloys Section: Carbon and Low-Alloy Steels; ASM International: Cleveland, OH, USA, 1990; Volume 1.

2. Hall, A.M.; Slunder, C. The Metallurgy, Behavior, and Application of the 18-Percent Nickel Maraging Steels; Battelle Memorial Institute: Columbus, OH, USA, 1968.

3. Mooney, B.; Kourousis, K. A Review of Factors Affecting the Mechanical Properties of Maraging Steel 300 Fabricated via Laser Powder Bed Fusion. Metals 2020, 10, 1273. [CrossRef]

4. Sun, H.; Chu, X.; Liu, Z.; Gisele, A.; Zou, Y. Selective laser melting of maraging steels using recycled powders: A comprehensive microstructural and mechanical investigation. Metall. Mater. Trans. A 2021, 52, 1714-1722. [CrossRef]

5. Saifullah, A.; Masood, S. Finite element thermal analysis of conformal cooling channels in injection moulding. In Proceedings of the 5th Australasian Congress on Applied Mechanics, Brisbane, Australia, 10-12 December 2007.

6. Feng, S.; Kamat, A.M.; Pei, Y. Design and fabrication of conformal cooling channels in molds: Review and progress updates. Int. J. Heat Mass Transf. 2021, 171, 121082. [CrossRef]

7. Da Fonseca, D.P.M.; Feitosa, A.L.M.; de Carvalho, L.G.; Plaut, R.L.; Padilha, A.F. A Short Review on Ultra-High-Strength Maraging Steels and Future Perspectives. Mater. Res. 2021, 24. [CrossRef]

8. Park, H.-S.; Dang, X.-P. Optimization of conformal cooling channels with array of baffles for plastic injection mold. Int. J. Precis. Eng. Manuf. 2010, 11, 879-890. [CrossRef]

9. Mazur, M.; Brincat, P.; Leary, M.; Brandt, M. Numerical and experimental evaluation of a conformally cooled H13 steel injection mould manufactured with selective laser melting. Int. J. Adv. Manuf. Technol. 2017, 93, 881-900. [CrossRef]

10. Meckley, J.; Edwards, R. A study on the design and effectiveness of conformal cooling channels in rapid tooling inserts. Technol. Interface J. 2009, 10, 1-28.

11. Bai, Y.; Yang, Y.; Xiao, Z.; Wang, D. Selective laser melting of maraging steel: Mechanical properties development and its application in mold. Rapid Prototyp. J. 2018, 24, 623-629. [CrossRef]

12. Vojnová, E. The Benefits of a Conforming Cooling Systems the Molds in Injection Moulding Process. Procedia Eng. 2016, 149, 535-543. [CrossRef]

13. Wiedenegger, A.; Bruckwilder, J.; Deutsch, C. Ecological and Economic Benefits of Additive Manufacturing in High Pressure Die Casting. BHM Berg Hüttenmänn. Mon. 2021, 166, 237-242. [CrossRef]

14. Wang, D.; Liu, Y.; Yang, Y.; Xiao, D. Theoretical and experimental study on surface roughness of 316L stainless steel metal parts obtained through selective laser melting. Rapid Prototyp. J. 2016, 22, 706-716. [CrossRef]

15. Yang, T.; Liu, T.; Liao, W.; MacDonald, E.; Wei, H.; Chen, X.; Jiang, L. The influence of process parameters on vertical surface roughness of the AlSi10Mg parts fabricated by selective laser melting. J. Mater. Process. Technol. 2019, 266, 26-36. [CrossRef]

16. Sames, W.J.; List, F.A.; Pannala, S.; Dehoff, R.; Babu, S. The metallurgy and processing science of metal additive manufacturing. Int. Mater. Rev. 2016, 61, 315-360. [CrossRef]

17. Lachmayer, R.; Lippert, R.B.; Kaierle, S. Additive Serienfertigung; Springer Vieweg: Berlin, Germany, 2018.

18. Du, W.; Bai, Q.; Zhang, B. A Novel Method for Additive/Subtractive Hybrid Manufacturing of Metallic Parts. Procedia Manuf. 2016, 5, 1018-1030. [CrossRef]

19. Casalino, G.; Campanelli, S.; Contuzzi, N.; Ludovico, A. Experimental investigation and statistical optimisation of the selective laser melting process of a maraging steel. Opt. Laser Technol. 2015, 65, 151-158. [CrossRef]

20. Bai, Y.; Yang, Y.; Wang, D.; Zhang, M. Influence mechanism of parameters process and mechanical properties evolution mechanism of maraging steel 300 by selective laser melting. Mater. Sci. Eng. A 2017, 703, 116-123. [CrossRef]

21. Suryawanshi, J.; Prashanth, K.; Ramamurty, U. Tensile, fracture, and fatigue crack growth properties of a 3D printed maraging steel through selective laser melting. J. Alloys Compd. 2017, 725, 355-364. [CrossRef] 
22. Tamura, S.; Matsumura, T.; Ezura, A.; Mori, K. Anisotropic Cutting Force Characteristics in Milling of Maraging Steel Processed Through Selective Laser Melting. J. Manuf. Sci. Eng. 2021, 144, 031012. [CrossRef]

23. Sugino, N.; Kurematsu, K.; Mizui, K.; Hanabata, M.; Takei, S. Improvement of Gas Permeability of Gas Permeable Mold with Lattice Structure for Reduction of Transfer Failure in Photoimprint Lithography. J. Photopolym. Sci. Technol. 2019, 32, 627-632. [CrossRef]

24. Enemuoh, E.U.; Carrillo, J.; Klein, J.; Cash, A.; Bergstrom, D. Characterization of Maraging Steel Fabricated with Metal Laser Sintering Hybrid Milling. In ASEE Annual Conference \& Exposition; ASEE American Society of Engineering Education: Washington, DC, USA, 2018.

25. Wüst, P.; Edelmann, A.; Hellmann, R. Areal Surface Roughness Optimization of Maraging Steel Parts Produced by Hybrid Additive Manufacturing. Materials 2020, 13, 418. [CrossRef]

26. Mutua, J.; Nakata, S.; Onda, T.; Chen, Z. Optimization of selective laser melting parameters and influence of post heat treatment on micro-structure and mechanical properties of maraging steel. Mater. Des. 2018, 139, 486-497. [CrossRef]

27. ASTM. B964-16 Standard Test Methods for Flow Rate of Metal Powders Using the Carney Funnel; ASTM International: West Conshohocken, PA, USA, 2016.

28. ASTM. B213-17 Standard Test Methods for Flow Rate of Metal Powders Using the Hall Flowmeter Funnel; ASTM International: West Conshohocken, PA, USA, 2017; pp. 1-4.

29. ASTM. B212-17 Standard Test Method for Apparent Density of Free-Flowing Metal Powders Using the Hall Flowmeter Funnel; ASTM International: West Conshohocken, PA, USA, 2017.

30. ASTM. B417-18 Standard Test Method for Apparent Density of Non-Free-Flowing Metal Powders Using the Carney Funnel; ASTM International: West Conshohocken, PA, USA, 2018.

31. Carr, R.L. Evaluating flow properties of solids. Chem. Eng. 1965, 18, 163-168.

32. Yablokova, G.; Speirs, M.; Van Humbeeck, J.; Kruth, J.-P.; Schrooten, J.; Cloots, R.; Boschini, F.; Lumay, G.; Luyten, J. Rheological behavior of $\beta$-Ti and NiTi powders produced by atomization for SLM production of open porous orthopedic implants. Powder Technol. 2015, 283, 199-209. [CrossRef]

33. ASTM. E8-04 Standard test methods for tension testing of metallic materials. In Annual Book of ASTM Standards; ASTM International: West Conshohocken, PA, USA, 2004.

34. ASTM. B311-17 Standard Test Method for Density of Powder Metallurgy (PM) Materials Containing Less Than Two Percent Porosity; ASTM International: West Conshohocken, PA, USA, 2017.

35. ASTM. B923-21 Standard Test Method for Metal Powder Skeletal Density by Helium or Nitrogen Pycnometry; ASTM International: West Conshohocken, PA, USA, 2021.

36. Sarafan, S.; Wanjara, P.; Lévesque, J.-B.; Gholipour, J.; Champliaud, H.; Mathieu, L. Residual Stresses, Microstructure, and Mechanical Properties of EB-Welded 90-mm-Thick UNS S41500 Martensitic Stainless Steel after PWHT. Mater. Perform. Charact. 2019, 8, 648-663. [CrossRef]

37. ASTM. E18-20 Standard Test Methods for Rockwell Hardness of Metallic Materials; ASTM International: West Conshohocken, PA, USA, 2020.

38. ASTM. E384-17 Standard Test Method for Microindentation Hardness of Materials; ASTM international: West Conshohocken, PA, USA, 2017.

39. Sarafan, S.; Wanjara, P.; Gholipour, J.; Champliaud, H.; Mathieu, L. Mehanical Properties of Electron Beam Welded Joints in Thick Gage CA6NM Stainless Steel. J. Mater. Eng. Perform. 2017, 26, 4768-4780. [CrossRef]

40. Kozak, J.; Zakrzewski, T. Accuracy problems of additive manufacturing using SLS/SLM processes. AIP Conf. Proc. 2018, 2017, 020010. [CrossRef]

41. Triantaphyllou, A.; Giusca, C.L.; Macaulay, G.D.; Roerig, F.; Hoebel, M.; Leach, R.; Tomita, B.; Milne, K.A. Surface texture measurement for additive manufacturing. Surf. Topogr. Metrol. Prop. 2015, 3, 024002. [CrossRef]

42. He, B.; Ding, S.; Shi, Z. A Comparison Between Profile and Areal Surface Roughness Parameters. Metrol. Meas. Syst. 2021, 28, 413-438.

43. Tan, C.; Zhou, K.; Tong, X.; Huang, Y.; Li, J.; Ma, W.; Li, F.; Kuang, T. Microstructure and mechanical properties of 18 Ni-300 maraging steel fabricated by selective laser melting. In Proceedings of the 2016 6th International Conference on Advanced Design and Manufacturing Engineering (ICADME 2016), Zhuhai, China, 23-24 July 2016.

44. EOS GmbH—Electro Optical Systems (EOS). EOS Maraging Steel MS1. In Material Data Sheet; EOSINT M280 \& EOSINT M270; EOS Gmbh: Munich, Germany, 2011.

45. Gu, D.; Shen, Y. Balling phenomena in direct laser sintering of stainless steel powder: Metallurgical mechanisms and control methods. Mater. Des. 2009, 30, 2903-2910. [CrossRef]

46. Rahmati, S.; Vahabli, E. Evaluation of analytical modeling for improvement of surface roughness of FDM test part using measurement results. Int. J. Adv. Manuf. Technol. 2015, 79, 823-829. [CrossRef]

47. Abele, E.; Kniepkamp, M. Analysis and optimisation of vertical surface roughness in micro selective laser melting. Surf. Topogr. Metrol. Prop. 2015, 3, 034007. [CrossRef]

48. Yadroitsev, I.; Smurov, I. Selective laser melting technology: From the single laser melted track stability to 3D parts of complex shape. Phys. Procedia 2010, 5, 551-560. [CrossRef] 
49. Khairallah, S.A.; Anderson, A.T.; Rubenchik, A.M.; King, W.E. Laser powder-bed fusion additive manufacturing: Physics of complex melt flow and formation mechanisms of pores, spatter, and denudation zones. Acta Mater. 2016, 108, 36-45. [CrossRef]

50. Zhang, B.; Li, Y.; Bai, Q. Defect Formation Mechanisms in Selective Laser Melting: A Review. Chin. J. Mech. Eng. 2017, 30, 515-527. [CrossRef]

51. Pekok, M.A.; Setchi, R.; Ryan, M.; Han, Q.; Gu, D. Effect of process parameters on the microstructure and mechanical properties of AA2024 fabricated using selective laser melting. Int. J. Adv. Manuf. Technol. 2021, 112, 175-192. [CrossRef]

52. DebRoy, T.; Wei, H.L.; Zuback, J.S.; Mukherjee, T.; Elmer, J.W.; Milewski, J.O.; Beese, A.M.; Wilson-Heid, A.; Zhang, W. Additive manufacturing of metallic components-process, structure and properties. Prog. Mater. Sci. 2018, 92, 112-224. [CrossRef]

53. Zhong, Y.; Liu, L.; Wikman, S.; Cui, D.; Shen, Z. Intragranular cellular segregation network structure strengthening 316L stainless steel prepared by selective laser melting. J. Nucl. Mater. 2016, 470, 170-178. [CrossRef]

54. Saeidi, K.; Gao, X.; Zhong, Y.; Shen, Z. Hardened austenite steel with columnar sub-grain structure formed by laser melting. Mater. Sci. Eng. A 2015, 625, 221-229. [CrossRef]

55. Tan, C.; Zhou, K.; Ma, W.; Zhang, P.; Liu, M.; Kuang, T. Microstructural evolution, nanoprecipitation behavior and mechanical properties of selective laser melted high-performance grade 300 maraging steel. Mater. Des. 2017, 134, 23-34. [CrossRef]

56. Paul, C.; Ganesh, P.; Mishra, S.; Bhargava, P.; Negi, J.; Nath, A. Investigating laser rapid manufacturing for Inconel-625 components. Opt. Laser Technol. 2007, 39, 800-805. [CrossRef]

57. Thijs, L.; Montero Sistiaga, M.L.; Wauthle, R.; Xie, Q.; Kruth, J.-P.; Van Humbeeck, J. Strong morphological and crystallographic texture and resulting yield strength anisotropy in selective laser melted tantalum. Acta Mater. 2013, 61, 4657-4668. [CrossRef]

58. Palad, R.; Tian, Y.; Chadha, K.; Rodrigues, S.; Aranas Jr, C. Microstructural features of novel corrosion-resistant maraging steel manufactured by laser powder bed fusion. Mater. Lett. 2020, 275, 128026. [CrossRef]

59. Chadha, K.; Tian, Y.; Bocher, P.; Spray, J.G.; Aranas, J.C. Microstructure Evolution, Mechanical Properties and Deformation Behavior of an Additively Manufactured Maraging Steel. Materials 2020, 13, 2380. [CrossRef] [PubMed]

60. Shamsdini, S.; Ghoncheh, M.H.; Sanjari, M.; Pirgazi, H.; Amirkhiz, B.S.; Kestens, L.; Mohammadi, M. Plastic deformation throughout strain-induced phase transformation in additively manufactured maraging steels. Mater. Des. 2021, $198,109289$. [CrossRef]

61. Gupta, R.; Mathew, C.; Ramkumar, P. Strain Hardening in Aerospace Alloys. Front. Aerosp. Eng. 2015, 4, 1-13. [CrossRef]

62. Becker, T.H.; Dimitrov, D. The achievable mechanical properties of SLM produced Maraging Steel 300 components. Rapid Prototyp. J. 2016, 22, 487-494. [CrossRef]

63. Casati, R.; Lemke, J.N.; Tuissi, A.; Vedani, M. Aging Behaviour and Mechanical Performance of 18-Ni 300 Steel Processed by Selective Laser Melting. Metals 2016, 6, 218. [CrossRef]

64. Frey, M.; Shellabear, M.; Thorsson, L. Whitepaper: Mechanical Testing of DMLS Parts; EOS GmbH: Munich, Germany, 2009.

65. Mooney, B.; Kourousis, K.I.; Raghavendra, R. Plastic anisotropy of additively manufactured maraging steel: Influence of the build orientation and heat treatments. Addit. Manuf. 2019, 25, 19-31. [CrossRef]

66. Wu, W.; Wang, X.; Wang, Q.; Liu, J.; Zhang, Y.; Hua, T.; Jiang, P. Microstructure and mechanical properties of maraging $18 \mathrm{Ni}-300$ steel obtained by powder bed based selective laser melting process. Rapid Prototyp. J. 2020, 26, 1379-1387. [CrossRef]

67. Kučerová, L.; Zetkova, I.; Jandová, A.; Bystrianský, M. Microstructural characterisation and in-situ straining of additivemanufactured X3NiCoMoTi 18-9-5 maraging steel. Mater. Sci. Eng. A 2019, 750, 70-80. [CrossRef]

68. Kempen, K.; Yasa, E.; Thijs, L.; Kruth, J.-P.; Van Humbeeck, J. Microstructure and mechanical properties of Selective Laser Melted 18Ni-300 steel. Phys. Procedia 2011, 12, 255-263. [CrossRef]

69. Strakosova, A.; Kubásek, J.; Michalcová, A.; Průša, F.; Vojtěch, D.; Dvorský, D. High Strength X3NiCoMoTi 18-9-5 Maraging Steel Prepared by Selective Laser Melting from Atomized Powder. Materials 2019, 12, 4174. [CrossRef] [PubMed] 